\title{
Diatoms in Volcanic Soils of Mutnovsky and Gorely Volcanoes (Kamchatka Peninsula, Russia)
}

\author{
Alfiya Fazlutdinova ${ }^{1}$, Yunir Gabidullin ${ }^{2} \mathbb{D}$, Rezeda Allaguvatova $^{3}\left(\mathbb{D}\right.$ and Lira Gaysina ${ }^{1,4, *(D)}$ \\ 1 Department of Bioecology and Biological Education, M. Akmullah Bashkir State Pedagogical University, \\ 450008 Ufa, Russia; alfi05@mail.ru \\ 2 Department of Information Systems and Technologies, M. Akmullah Bashkir State Pedagogical University, \\ 450008 Ufa, Russia; junigobi@gmail.com \\ 3 Laboratory of Botany, Federal Scientific Center of the East Asia Terrestrial Biodiversity, \\ 690022 Vladivostok, Russia; allaguvatova@yandex.ru \\ 4 All-Russian Research Institute of Phytopathology, 143050 Odintsovo, Russia \\ * Correspondence: lira.gaisina@gmail.com; Tel.: +7-906-3764252
}

check for updates

Citation: Fazlutdinova, A.; Gabidullin, Y.; Allaguvatova, R.; Gaysina, L. Diatoms in Volcanic Soils of Mutnovsky and Gorely Volcanoes (Kamchatka Peninsula, Russia). Microorganisms 2021, 9, 1851. https://doi.org/10.3390/ microorganisms 9091851

Academic Editors: Fernando Puente-Sánchez and Max Chavarría

Received: 11 August 2021

Accepted: 27 August 2021

Published: 31 August 2021

Publisher's Note: MDPI stays neutral with regard to jurisdictional claims in published maps and institutional affiliations.

Copyright: (c) 2021 by the authors. Licensee MDPI, Basel, Switzerland. This article is an open access article distributed under the terms and conditions of the Creative Commons Attribution (CC BY) license (https:// creativecommons.org/licenses/by/ $4.0 /)$.

\begin{abstract}
Volcanic activity has a great impact on terrestrial ecosystems, including soil algae in general and diatoms in particular. To understand the influence of volcanoes on the biodiversity of diatoms, it is necessary to explore the flora of these microorganisms in regions with high volcanic activity, which includes the Kamchatka peninsula. During the study on diatoms in the soils of Mutnovsky and Gorely volcanoes of Kamchatka, 38 taxa were found. The Mutnovsky volcano diatom flora was more diverse and accounted for 35 taxa. Eunotia curtagrunowii, Humidophila contenta, and Pinnularia borealis were the dominant species. In the Gorely volcano, only 9 species were identified, with Caloneis bacillum and Pinnularia borealis prevailing in the samples. Overall, the genera Pinnularia and Eunotia were the most diverse in the studied area. The diatom flora of the studied volcanoes comprises mostly cosmopolitan small-sized taxa with a wide range of ecological plasticity. Our data confirm the high adaptive potential of diatom algae and add new knowledge about the ecology and biogeography of this group of microorganisms.
\end{abstract}

Keywords: volcanic eruptions; lifeless substrates; restoration; biodiversity; Southern Kamchatkan subduction zone; Mutnovsky geothermal field; Eunotia curtagrunowii; Humidophila contenta; Caloneis bacillum; Pinnularia borealis

\section{Introduction}

Volcanoes, microorganisms, and water are important factors supporting life on our planet. Fossil records confirm that volcanic glass serves as a bioreactor for generating microbial life [1]. Volcanic activity has a great impact on the development of terrestrial ecosystems due to the influence of various chemical elements with volcanic emissions, changes in the temperature regime, transformations of existing landscapes, and the creation of new environment [2].

Algae (including diatoms) are among the first microorganisms that settle on lifeless substrates after a volcanic eruption and initiate the succession during their overgrowth $[3,4]$.

The study of the colonization of volcanic substrates by algae has been associated with the largest volcanic eruptions [5]. These studies started in 1886 when the eruption of the Krakatoa volcano led to the immersion of most of the island underwater and the "sterilization" of the rest of its surface. Cyanobacteria were the first organisms that settled on the volcanic surface, and they played the most important role in the colonization of the lifeless volcanic substrate [6].

The next stage in the study of the algal flora of volcanic emissions began after the eruption of an underwater volcano near the coast of Iceland and the emergence of Surtsey Island in 1963 [4,7-11]. At the initial stages of the appearance of the vegetation currently 
covering this island, diatoms and green algae prevailed in the algal flora. In total, 71 species of diatoms, including numerous aquatic forms, were identified [12]. Cyanobacteria and yellow-green and euglenoid algae were much fewer in number.

A well-studied example of the colonization and succession of cyanobacteria and algae in another volcanically active region-the Hawaiian Islands-was described in the literature. A positive correlation between the diversity and abundance of algae with the level of nutrients and the accumulation of organic matter was revealed here [13].

In the study of the communities of soil algae inhabiting andosols with volcanic glasses on Deception Island [14,15], cyanobacteria and diatoms were dominant in the algal communities.

Volcanic ashes are low in organic nutrients and energy sources; therefore, only microorganisms with an economical metabolism and specific adaptations to this environment can survive $[16,17]$. Different types of soils can be formed from volcanic ash depending on the characteristics of the soil-forming process in a particular habitat [18].

Green algae form a mucilage, stabilizing the fine-grained volcanic soil. In addition, the mucilage protects them from water fluctuations and defends the cells from loss of water [19]. It has been shown that diatoms precipitate silicon and calcite, which can also contribute to the aggregation of mineral particles [20].

Kamchatka is part of the Kuril-Kamchatka island (or volcanic) arc. It is one of the most seismically active regions on the Earth, with about 30 active and potentially active volcanoes in the Kuril-Kamchatka region [21-23]. As a result of the eruptions of these volcanoes, millions of tons of volcanic ash are emitted into the atmosphere [24].

Information on the algae of Kamchatka's volcano soils is limited and based on a sporadic sampling. The numerous hot springs associated with volcanic activity have traditionally attracted a great deal of attention from researchers [25-28]. At the same time, there is evidence that volcanic soils can harbor a significant diversity of algae and cyanobacteria [5,29]. In soils of the Kuril-Kamchatka group of volcanoes-Tyatya, Golovin, and Mendeleev on Kunashir Island and Tolbachik in Kamchatka-74 species of algae were found. A few species of algae were also reported from the lava caves of the Gorely volcano [30]. As stated before, diatoms play an important part in the primary succession of volcanic substrates, but the data about the biodiversity of diatoms of volcano soils, including Kamchatka soils, are very limited.

Our study aimed to investigate the diversity of diatoms in volcano soils of Mutnovsky and Gorely volcanoes, which are some of the active volcanoes of Kamchatka [31,32] and can be considered as model objects for observing the colonization of lifeless volcanic substrates by microorganisms.

\section{Materials and Methods}

\subsection{Studied Area}

The Kamchatkan peninsula is one of the most active volcanic regions on the Earth [33] (Figure 1). The geochemistry of the Kamchatka volcanic rocks is typical of global arc volcanism. They contain a high amount of large ion lithophile elements such as $\mathrm{Rb}, \mathrm{Ba}, \mathrm{K}$, $\mathrm{Pb}$, and $\mathrm{Sr}$ in comparison with high field strength elements such as $\mathrm{Nb}, \mathrm{Zr}$, and $\mathrm{Ti}$ [34-37].

Mutnovsky and Gorely volcanoes belong to the Mutnovsky geothermal field, which is part of the Mutnovsky geothermal region with an area of about $750 \mathrm{~km}^{2}$ [38] (Figure 1). The territory of the geothermal field is a volcanic plateau at 700-900 m a.s.l. elevation divided by the Falshivaya, Mutnovskaya, and Zhirovaya rivers. The Mutnovsky geothermal field is characterized by numerous thermal water and steam discharges, scoria cones, and extrusive bodies, together with hydrothermally altered rocks [38-40]. The composition of volcanic rocks in the region includes tuff and lava of andesite, andesidacite, and andesibasalt with inclusions of subvolcanic bodies and dikes of variable composition (diorite, dioritic porphyrite, basalt) $[38,40,41]$ (Table 1 ). 


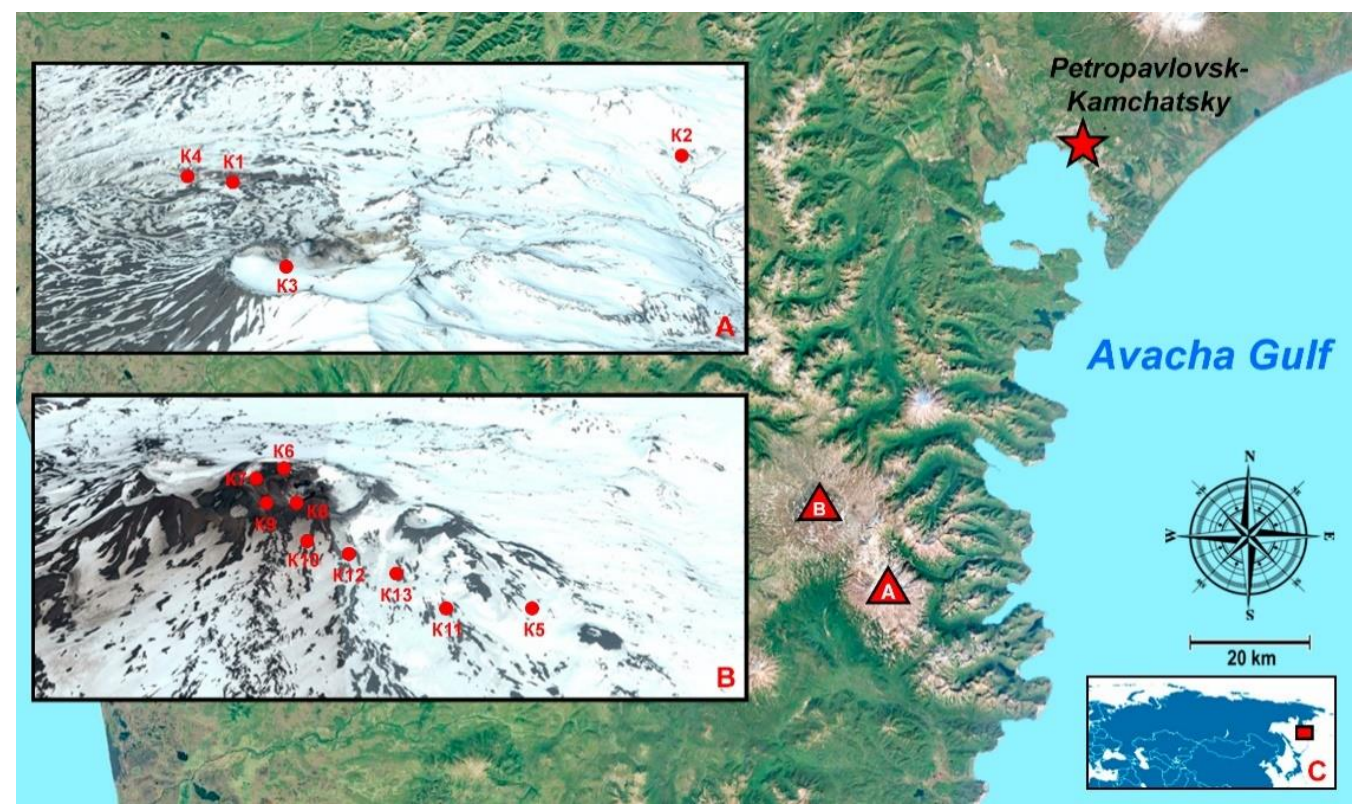

Figure 1. Study area. The red star indicates Petropavlovsk-Kamchatsky city; red triangle with letter (A) - Gorely volcano, red triangle with letter (B)-Mutnovsky volcano; (A)-Mutnovsky volcano, red dots indicate sites $\mathrm{K} 1-\mathrm{K} 4$; (B)—Gorely volcano, red dots indicate sites $\mathrm{K} 5-\mathrm{K} 13$; (C)—red rectangle indicates the Kamchatka peninsula.

Due to the open position and windwardness of both slopes, the area has similar weather conditions on the eastern and western slopes of the volcanic highlands [42]. The eastern slopes receive the maximum precipitation for the whole of Kamchatka, at $2500 \mathrm{~mm}$ per year. High humidity, heavy rainfall, and frequent hurricane winds create extremely unfavorable weather conditions in the area. Because of the small width of the peninsula, the influence of the Pacific Ocean is great [43].

The studied area is located in the southeastern soil province [44], which belongs to the zone of stone birch forests. The volcanic soils of Kamchatka are distinctive for the very low values of the potential buffering capacity for potassium [45] and the increased content of copper, manganese, scandium, vanadium, and silver against the background of low concentrations of other microelements [46]. The surface organogenic horizon within the province was formed on andesite-basaltic gray coarse-grained ash of the eruption of the Ksudach volcano in 1907. All ash horizons, except for the near-surface horizon, are predominantly acidic. The humus content in organogenic horizons is high, at up to $5-10 \%$. The reaction of the environment in soils is acidic and slightly acidic. The degree of saturation with bases is low: on average, $8-11 \%$. The ocher illuvial horizons are characterized by the accumulation of soluble forms of iron and aluminum up to $3 \%$ and $8 \%$. In the elfin belt at an altitude of $700-1000 \mathrm{~m}$, there are humus-ocher soils (under alder forests), peaty illuvial-humus soils, and peaty illuvial-humus volcanic soils (under cedar forests). The soils of the subalpine elfin zone are characterized by the peaty character of the modern organogenic horizon, the humus or one and a half-turfy nature of the buried organogenic horizons, the predominance of brown tones in the color of the illuvial-metamorphic horizons, the retardation (in comparison with the forest zone) of the processes of weathering and the accumulation of amorphous substances, high acidity, and unsaturation [47]. 
The vegetation cover is characterized by a significant decrease in the altitudinal vegetation belts [48]. The vegetation cover of the studied volcanoes is dominated by elite forests and mountain tundra. The surfaces of loose volcanic deposits are almost lacking vegetation.

The Mutnovsky volcano is situated $70 \mathrm{~km}$ southwest of Petropavlovsk-Kamchatsky on the Kamchatka Peninsula. Mutnovsky belongs to the Eastern Volcanic Front-one of the three major volcanic chains in Kamchatka, which were created by the northwestdirected subduction of the Pacific Plate [49]. The Mutnovsky volcano is an elongated massif consisting of four merged cones. The explosions, which took place in several stages, first formed two huge craters in the southwest and northeast, resembling a figure eight and stretching for $4 \mathrm{~km}$. The merged crater of the Mutnovsky volcano with a height of $2323 \mathrm{~m}$ is the largest among the craters of active volcanoes in Kamchatka. The diameter of the craters reaches $1.5-2 \mathrm{~km}$, and the depth is $400 \mathrm{~m}$. Subsequent explosions in the southwest crater formed a deep funnel, previously occupied by a lake and now by a glacier. In addition, the active funnel is superimposed on the northern edge of the southwest crater, which is a closed bowl with a depth of about $150 \mathrm{~m}$, with steep walls and a flat bottom that is $100 \times 150 \mathrm{~m}$ in diameter. The Vulkannaya River, cutting through the bottom and western walls of the northern crater, forms a powerful $80 \mathrm{~m}$ waterfall at the exit, and below, it forms a deep canyon-the Opasny Ravine [50].

In the craters of the volcano and on its northern slope, there are high-temperature fumaroles; steam-gas jets, the outlets of which are framed by volcanic sulfur; and thermal springs in the form of water and mud pots. The most intense fumarolic activity is concentrated mainly in the northeast crater and the active funnel. In the first crater, three groups of steam-gas outlets are constantly operating - this is the upper fumarole field, with fumarole temperatures of more than $300{ }^{\circ} \mathrm{C}$-and two relatively isolated groups on the Donnoye fumarole field are present with outlet temperatures up to $150{ }^{\circ} \mathrm{C}$. In the active funnel, the most powerful gas activity is concentrated on the southwestern wall [50].

The production of mostly low $\mathrm{K}$ basaltic lavas with rare earth element patterns is a unique feature of Mutnovsky. This feature is similar to the classic island arc tholeiites [51]. Mutnovsky lavas belong to a tholeiitic igneous series with $48-70 \% \mathrm{SiO}_{2}$. Basalts and basaltic andesites have relatively low $\mathrm{K}_{2} \mathrm{O}$ and $\mathrm{Na}_{2} \mathrm{O}$ and high $\mathrm{FeO}^{*}$ and $\mathrm{Al}_{2} \mathrm{O}_{3}$ in comparison with other Kamchatka volcanic rocks [49].

The Gorely volcano is situated $75 \mathrm{~km}$ southwest of Petropavlovsk-Kamchatsky. It has a height of $1800 \mathrm{~m}$ [52]. The Gorely volcano consists of two large parts: an ancient shield-like structure, crowned with a $13 \mathrm{~km}$ caldera, and a modern structure like a complex stratovolcano. The modern structure covers an area of $150 \mathrm{~km}^{2}$, located in the center of the caldera, and is composed mainly of basaltic and andesite-basaltic lavas. The structure itself and the morphology of the streams resemble the Hawaiian type of volcanic manifestation. Its top is framed by a chain of explosive craters, and about 30 flank cones are noted on the slopes [50,53-55]. The ancient part of the volcano covers an area of $650 \mathrm{~km}$. Its gentle slopes can be traced in the north to the upper reaches of the river Paratunka, northeast to the headwaters of the river Zhirovaya, in the east to the Falshivaya and Vulkannaya rivers, in the south to the northern slopes of the Asach volcano, and in the west to Tolmachev Dol. The structure is composed of andesite-basalt and andesite lavas and mainly pyroclastics of andesite-dacite and dacite composition. Lavas and extrusions of liparite rhyolites are found here in small quantities. Of greatest interest are pyroclastic formations such as sintered tuffs and ignimbrites. In the sections of the walls, cutting through the edifice, one can trace here the transformation of pyroclastic material from loose pumice to sintered tuffs and ignimbrites, as well as tuff lava [50]. 
Table 1. Comparisons of the geochemistry of Mutnovsky and Gorely volcanoes [31,47,49,56-59].

\begin{tabular}{|c|c|c|}
\hline & Mutnovsky Volcano & Gorely Volcano \\
\hline $\begin{array}{l}\text { Volcanic composition and } \\
\text { chemical content of the rocks }\end{array}$ & $\begin{array}{l}\text { Basalts and basaltic andesites with relatively } \\
\text { low } \mathrm{K}_{2} \mathrm{O} \text { and } \mathrm{Na}_{2} \mathrm{O} \text { and high } \mathrm{FeO}^{*} \text { and } \mathrm{Al}_{2} \mathrm{O}_{3} \\
\text { two-peroxene dacites, composed mainly of } \\
\text { low-potassium and calc-alkaline basalts. } \\
\text { In terms of } \mathrm{SiO}_{2}-\mathrm{K}_{2} \mathrm{O} \text { relations, they belong to } \\
\text { the low- and moderate-potassium varieties of } \\
\text { the calc-alkaline series, plotting along with the } \\
\text { tholeiitic-calc-alkaline series; in terms of the } \\
\text { alumina index, they are moderately aluminous } \\
\text { rocks. The young basalts are enriched in } \mathrm{MgO} \\
\text { and } \mathrm{CaO} \text { but differ in low contents of } \mathrm{SiO}_{2} \text {, } \\
\qquad \mathrm{TiO}_{2}, \mathrm{Al}_{2} \mathrm{O}_{3} \text {, and } \mathrm{Na}_{2} \mathrm{O} \text {. }\end{array}$ & $\begin{array}{l}\text { Basalts and andesitodacites with low } \mathrm{K}_{2} \mathrm{O} \text {, } \\
\text { high contents of } \mathrm{CaO}, \mathrm{TiO}_{2} \text {, and total iron, with } \\
\text { a predominance of intermediate basaltic } \\
\text { andesite rocks. } \\
\text { All varieties of young volcanic rocks have } \\
\text { elevated } \mathrm{K}_{2} \mathrm{O} \text { contents and correspond to the } \\
\text { high potassium calc-alkaline series, with } \\
\text { normal alkalinity. Some lavas of the youngest } \\
\text { eruptions have elevated alkali contents and } \\
\text { correspond to the subalkaline series. Most } \\
\text { lavas of the riftogenic zone are clustered } \\
\text { around the dividing line of the } \\
\text { calc-alkaline-tholeiitic series. }\end{array}$ \\
\hline $\mathrm{pH}$ of constituent rocks & $10-15 \%$ of acid-medium rocks & Acid andesites \\
\hline Last eruption & March 2000 & Summer 2010 \\
\hline Concentration of $\mathrm{SiO}_{2}$ & $48-70 \%$ & $51-57 \%$ \\
\hline Tephra & $\begin{array}{c}\text { Gravel and lapilli of dense andesite with } \\
\text { interlayers of yellowish silty sands, thin ashes } \\
\text { with the inclusion of larger grains of sand } \\
\text { and gravel }\end{array}$ & Black-gray volcanic sand and slag \\
\hline
\end{tabular}

\subsection{Sample Collection}

Volcanic soil samples were collected in August 2010 from 13 sites (Table 2, Figure 2). Samples (100 g of soil) were taken with metal cylinders, according to the terrestrial diatom sampling method [60], and put into sterile paper bags. The samples were examined according to previously described methods [28]. For diatom cell cleaning, $1 \mathrm{~g}$ of each soil sample was diluted with $10 \mathrm{~mL}$ of deionized water and $10 \mathrm{~mL}$ of nitric acid. For water evaporation, the mixture was boiled to a double volume reduction and, after cooling to room temperature, was washed four times using deionized water.

Diatom cells were settled by sedimentation during the washing procedure. Then, suspensions of the washed cells were dried on glass coverslips and mounted on permanent slides with Naphrax following standard methods [61]. Diatoms were examined at 1000× magnification, using Zeiss Axio Imager A2 light microscopes (Carl Zeiss, Jena, Germany), equipped with oil immersion objectives with differential interference contrast (DIC) and Axio Cam MRc cameras. Permanent slides were deposited in the Bashkortostan Collection of Algae and Cyanobacteria (BCAC) (WDCM 1023, Ufa, Russia). The identification of species was conducted using relevant references [62-66] and recent publications [67-70]. For descriptions of the ecology of species, standard flora and related literature data were used [71-79].

The floristic similarity of volcanoes was accessed with the Sørensen-Czekanowski coefficient [28]. 
Table 2. Sampling sites.

\begin{tabular}{|c|c|c|c|c|c|c|c|}
\hline Number & Description & Name & GPS * & Area & $\mathrm{pH}$ & Humidity, \% & Type of Soil \\
\hline 1 & $\begin{array}{l}\text { Canyon of the } \\
\text { Vulkannaya river, } \\
\text { under the bushes }\end{array}$ & K1 & $\begin{array}{l}52^{\circ} 28^{\prime} 29.4^{\prime \prime} \mathrm{N} \\
158^{\circ} 06^{\prime} 47.8^{\prime \prime} \mathrm{E}\end{array}$ & $M^{* *}$ & 9.1 & $50-68$ & $\begin{array}{l}\text { Mountain-tundra } \\
\text { illuvial-humus soils }\end{array}$ \\
\hline 2 & $\begin{array}{l}\text { At the base of the } \\
\text { volcano, not far from } \\
\text { Dachnye springs, } \\
\text { alder forest }\end{array}$ & K2 & $\begin{array}{l}52^{\circ} 31^{\prime} 54.6^{\prime \prime} \mathrm{N} \\
158^{\circ} 11^{\prime} 55.0^{\prime \prime} \mathrm{E}\end{array}$ & M & 8.9 & $75-85$ & Humus-ocher soils \\
\hline 3 & $\begin{array}{l}300 \mathrm{~m} \text { from the top } \\
\text { of the volcano }\end{array}$ & $\mathrm{K} 3$ & $\begin{array}{l}52^{\circ} 27^{\prime} 26.4^{\prime \prime} \mathrm{N} \\
158^{\circ} 09^{\prime} 50.4^{\prime \prime} \mathrm{E}\end{array}$ & M & 9.1 & $40-50$ & $\begin{array}{l}\text { Stone talus and } \\
\text { placers, rocks }\end{array}$ \\
\hline 4 & $\begin{array}{l}\text { In the lower part of } \\
\text { the Vulkannaya } \\
\text { River canyon }\end{array}$ & $\mathrm{K} 4$ & $\begin{array}{l}52^{\circ} 28^{\prime} 17.3^{\prime \prime} \mathrm{N} \\
158^{\circ} 06^{\prime} 02.4^{\prime \prime} \mathrm{E}\end{array}$ & M & 9.1 & $50-58$ & Rocks \\
\hline 5 & $\begin{array}{l}\text { Slope, flat area } \\
\text { among sedges }\end{array}$ & K5 & $\begin{array}{l}52^{\circ} 32^{\prime} 35.0^{\prime \prime} \mathrm{N} \\
158^{\circ} 03^{\prime} 58.2^{\prime \prime} \mathrm{E}\end{array}$ & $G^{* * *}$ & 5.8 & $60-70$ & $\begin{array}{c}\text { Illuvial-humus } \\
\text { volcanic destructive } \\
\text { soils }\end{array}$ \\
\hline 6 & $\begin{array}{l}\text { The trail along the } \\
\text { edge of the crater, } \\
\text { green layer on the } \\
\text { surface of the } \\
\text { ground }\end{array}$ & K6 & $\begin{array}{l}52^{\circ} 33^{\prime} 26.4^{\prime \prime} \mathrm{N} \\
158^{\circ} 02^{\prime} 09.2^{\prime \prime} \mathrm{E}\end{array}$ & G & 9.0 & $50-65$ & Volcanic ash, sand \\
\hline 7 & Down the east slope & K7 & $\begin{array}{l}52^{\circ} 33^{\prime} 19.1^{\prime \prime} \mathrm{N} \\
158^{\circ} 01^{\prime} 57.4^{\prime \prime} \mathrm{E}\end{array}$ & G & 9.2 & $55-65$ & $\begin{array}{l}\text { Tundra volcanic } \\
\text { illuvial-humus soils }\end{array}$ \\
\hline 8 & $\begin{array}{l}\text { At the edge of a } \\
\text { crater with a lake }\end{array}$ & K8 & $\begin{array}{l}52^{\circ} 33^{\prime} 12.8^{\prime \prime} \mathrm{N} \\
158^{\circ} 02^{\prime} 20.7^{\prime \prime} \mathrm{E}\end{array}$ & G & $5.0-6.0$ & $40-50$ & $\begin{array}{l}\text { Sulfur deposits } \\
\text { around the crater }\end{array}$ \\
\hline 9 & Down the east slope & K9 & $\begin{array}{l}52^{\circ} 33^{\prime} 10.8^{\prime \prime} \mathrm{N} \\
158^{\circ} 02^{\prime} 06.0^{\prime \prime} \mathrm{E}\end{array}$ & G & $5.0-6.5$ & $55-65$ & $\begin{array}{l}\text { Tundra volcanic } \\
\text { illuvial-humus soils }\end{array}$ \\
\hline 10 & Down the east slope & K10 & $\begin{array}{l}52^{\circ} 32^{\prime} 53.7^{\prime \prime} \mathrm{N} \\
158^{\circ} 02^{\prime} 21.6^{\prime \prime} \mathrm{E}\end{array}$ & G & $5.2-6.3$ & $55-65$ & $\begin{array}{l}\text { Tundra volcanic } \\
\text { illuvial-humus soils }\end{array}$ \\
\hline 11 & $\begin{array}{c}1000 \mathrm{~m} \text { from the top } \\
\text { of the volcano }\end{array}$ & K11 & $\begin{array}{l}52^{\circ} 32^{\prime} 27.8^{\prime \prime} \mathrm{N} \\
158^{\circ} 03^{\prime} 22.0^{\prime \prime} \mathrm{E}\end{array}$ & G & $5.2-6.3$ & $55-65$ & $\begin{array}{l}\text { Tundra volcanic } \\
\text { illuvial-humus soils }\end{array}$ \\
\hline 12 & $\begin{array}{l}\text { An active crater } \\
\text { during the sampling, } \\
500 \mathrm{~m} \text { from the top } \\
\text { of the volcano }\end{array}$ & K12 & $\begin{array}{l}52^{\circ} 32^{\prime} 46.2^{\prime \prime} \mathrm{N} \\
158^{\circ} 02^{\prime} 39.9^{\prime \prime} \mathrm{E}\end{array}$ & G & $8.4-9.0$ & - & Volcanic ash, sand \\
\hline 13 & $\begin{array}{l}800 \mathrm{~m} \text { from the top } \\
\text { of the volcano, rare } \\
\text { vegetation }\end{array}$ & K13 & $\begin{array}{l}52^{\circ} 32^{\prime} 38.7^{\prime \prime} \mathrm{N} \\
158^{\circ} 03^{\prime} 03.1^{\prime \prime} \mathrm{E}\end{array}$ & G & $5.2-6.3$ & $65-70$ & $\begin{array}{c}\text { Tundra volcanic } \\
\text { illuvial-humus soils }\end{array}$ \\
\hline
\end{tabular}

Notes. ${ }^{*}$ positions of the sites in the map indicated on Figure $1 ; \mathrm{M}^{* *}$-Mutnovsky Volcano; $\mathrm{G}^{* * *}$-Gorely Volcano.

For the comparison and visualization of the similarities between diatom communities from Mutnovsky and Gorely volcanoes, a Venn diagram was used [80,81]. The Venn diagram was created with the InteractiVenn tool [82].

The abundance of the diatom species was estimated with the previously described method [28,83]. According to this method, the minimum abundance of algae was 1 point (1-15 on a slide) and the maximum abundance was 15 points (more than 50 on a slide). Species with an abundance of 13-15 points were dominant in the sample. 


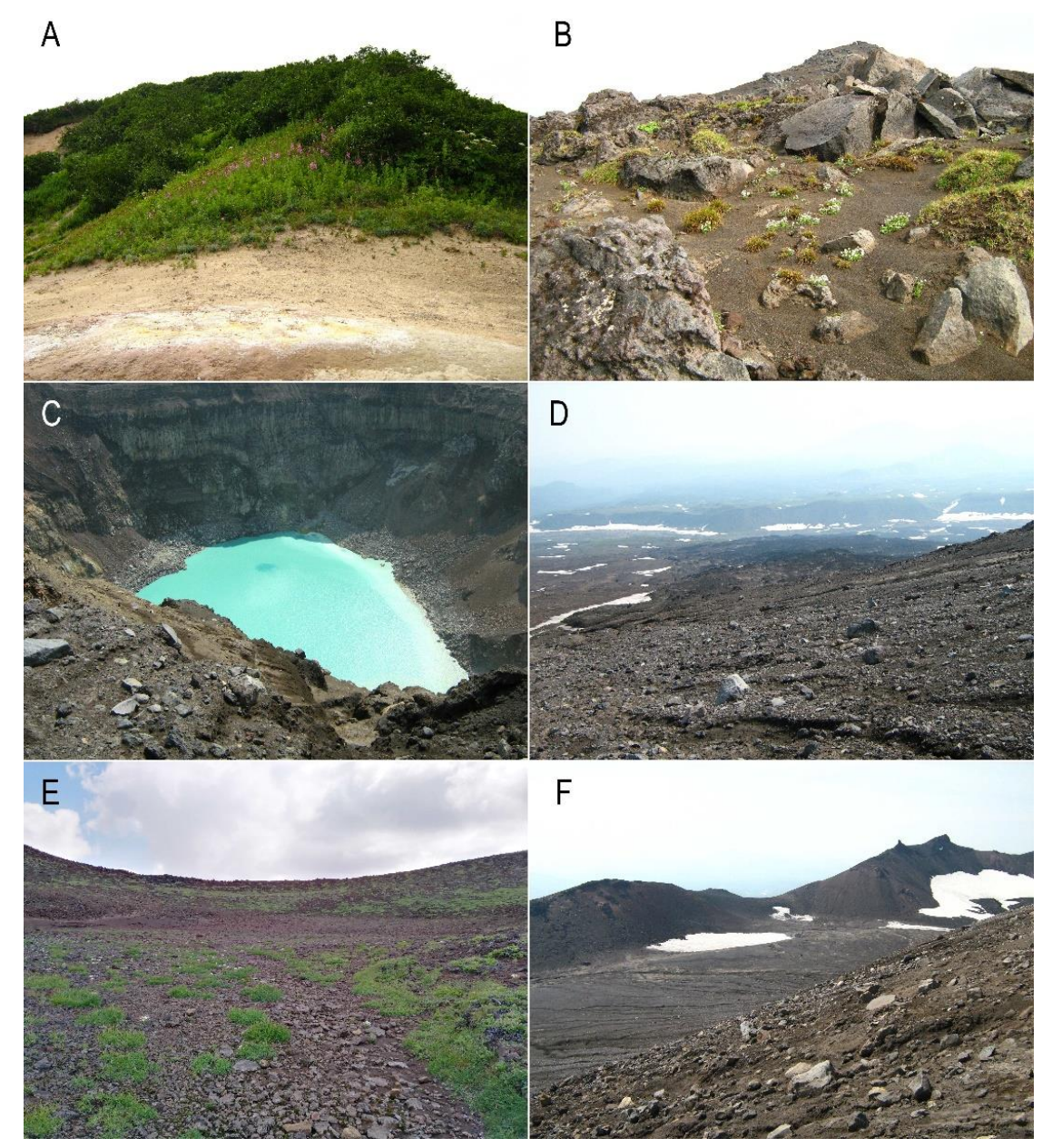

Figure 2. Study sites: (A) K2, alder forest at the base of the Mutnovsky volcano; (B) K5, flat area among sedges near the Gorely volcano; (C) K6, trail along the edge of the Gorely crater; (D) K10, down the east slope of the volcano; (E) K11, $1000 \mathrm{~m}$ from the top of the Gorely volcano; (F) K13, $800 \mathrm{~m}$ from the top of the volcano.

\section{Results}

In volcanic soils of Mutnovsky and Gorely volcanoes, 38 taxa of diatoms from 20 genera, such as Adlafia Gerd Moser, Lange-Bertalot and Metzeltin, Caloneis Cleve, Diatoma Bory, Eunotia Ehrenberg, Fragilariforma D.M. Williams and Round, Gomphonema Ehrenberg, Hantzschia Grunow, Humidophila (Lange-Bertalot and Werum) R.L.Lowe and al., Luticola D.G.Mann, Muelleria (Frenguelli) Frenguelli, Navicula Bory, Nitzschia Hass, Pinnularia Ehrenberg, Planothidium Round and L.Bukhtiyarova, Platessa Lange-Bertalot, Psammothidium L.Buhtkiyarova and Round, Sellaphora Mereschowsky, Stauroneis Ehrenberg, Staurosirella D.M.Wiliams and Round, and Tabullaria (Kützing) D.M.Williams and Round were identified (Figure 3A-W, Table 3). The genera Pinnularia (seven species), Eunotia (five species), and Caloneis (three species) were the richest in terms of the number species and were recorded in almost all the samples studied. On average, we found 6.6 species per sample, but the number of species increased with the distance from the volcanic craters. In the samples $\mathrm{K} 6$ on the trail along the edge of the crater, $\mathrm{K} 7$ down the east slope, and $\mathrm{K} 8$ at the edge of a crater with a lake from the Gorely volcano, diatoms were not found. In the samples $\mathrm{K} 12$, K13, and K11, three, one, and seven taxa were detected, respectively. Similarly, on the Mutnovsky volcano, in sample K3 $300 \mathrm{~m}$ from the top of the volcano, 5 diatom species were identified; in K1 in the bushes, K2 in alder forest, and K4 in the Vulkannaya River canyon, 13, 22, and 9 taxa were found, respectively (Tables 2 and 3). 


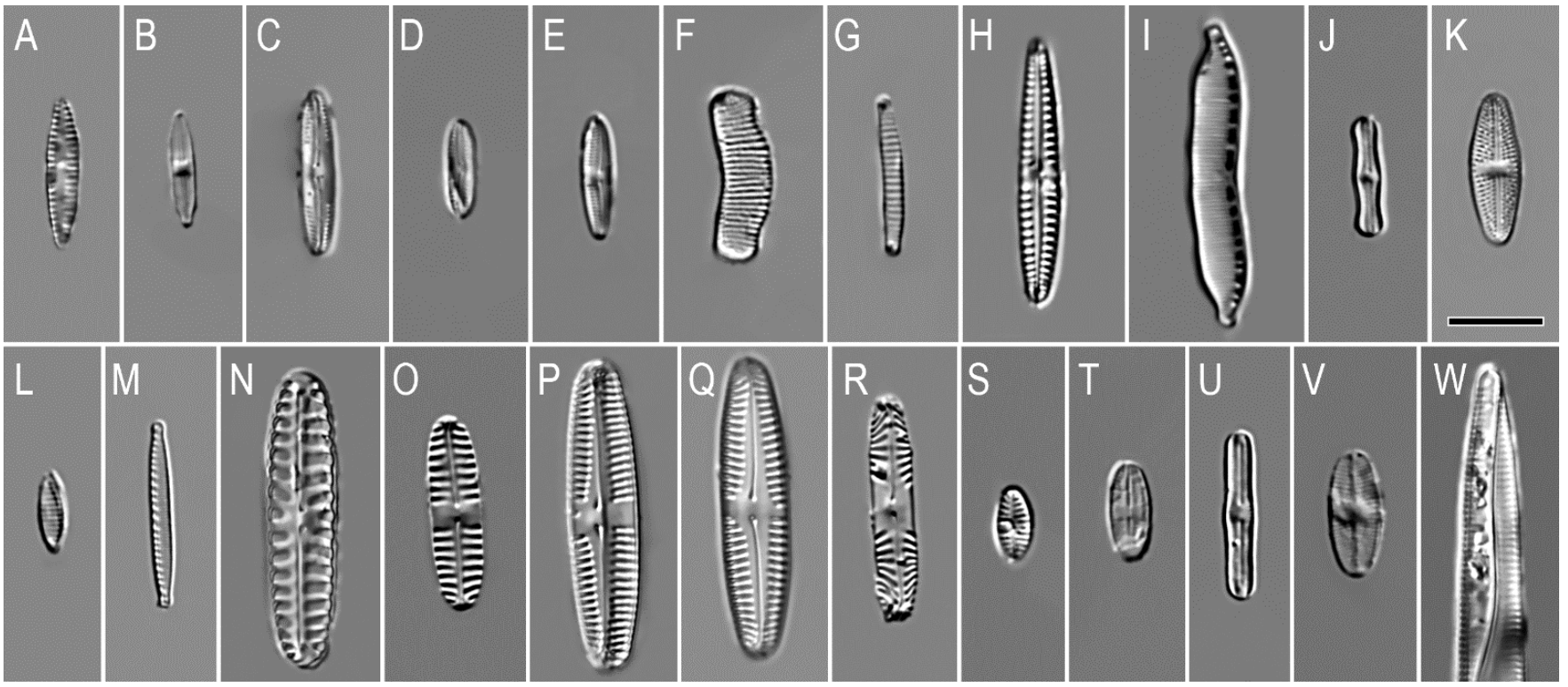

Figure 3. Species of diatoms from Mutnovsky and Gorely volcano soils: (A) Achnanthes linearis var. pusilla; (B) Adlafia aquaeductae; (C) Caloneis bacillum; (D) Caloneis dubia; (E) Caloneis lancettula; (F) Eunotia curtagrunowii; (G) Eunotia fallax; (H) Gomphonema parvulum; (I) Hantzschia amphioxys; (J) Humidophila contenta; (K) Luticola mutica; (L) Nitzschia cf. ovalis; (M) Nitzschia palea; (N) Pinnularia borealis; (O) Pinnularia intermedia; (P) Pinnularia sp.1; (Q) Pinnularia sp.2; (R) Pinnularia cf. subcapitata; (S) Planothidium lanceolatum; (T) Platessa oblongella; (U) Psammothidium ventrale; (V) Sellaphora bacillum; (W) Tabularia fasciculata.

Table 3. Diatom taxa recorded at each sampling site.

\begin{tabular}{|c|c|c|c|c|c|c|c|c|c|c|c|c|c|}
\hline \multirow{2}{*}{ Taxa } & \multicolumn{4}{|c|}{ Mutnovsky Volcano } & \multicolumn{9}{|c|}{ Gorely Volcano } \\
\hline & K1 & $\mathrm{K} 2$ & K3 & K4 & K5 & K6 & K7 & K8 & K9 & K10 & K11 & K12 & K13 \\
\hline Achnanthes linearis var. pusilla Grunov & & 2 & & & & & & & & & & & \\
\hline Adlafia aquaeductae (Krasske) Lange-Bertalot & & 3 & & & & & & & & & & & \\
\hline Caloneis bacillum (Grunow) Cleve & 5 & & 2 & 6 & 6 & & & & & & 15 & & 15 \\
\hline $\begin{array}{c}\text { Caloneis lancettula (Schulz) Lange-Bertalot } \\
\text { et Witkowski }\end{array}$ & & & & & & & & & & & 1 & & \\
\hline Caloneis dubia Krammer & 1 & & & & & & & & & & & & \\
\hline Diatoma tenuis Agardh & 3 & & & & & & & & & & & & \\
\hline Diatoma vulgaris Bory & & 1 & & & & & & & & & & & \\
\hline $\begin{array}{l}\text { Eunotia bilunaris (Ehrenberg) } \\
\text { Schaarschmidt }\end{array}$ & & 1 & & & & & & & & & & & \\
\hline $\begin{array}{l}\text { Eunotia curtagrunowii Nörpel-Schempp and } \\
\text { Lange-Bertalot }\end{array}$ & & 15 & & & & & & & & & 1 & & \\
\hline Eunotia fallax A. Cleve & 10 & 6 & & & & & & & & & & & \\
\hline Eunotia paludosa Grunow & 2 & & & & & & & & & & & & \\
\hline $\begin{array}{l}\text { Eunotia sudetica f. minor Manguin in } \\
\text { Bourrelly et Manguin }\end{array}$ & & 3 & & & & & & & & & & & \\
\hline $\begin{array}{l}\text { Fragilariforma virescens var. exigua (Grunow) } \\
\text { M.Poulin }\end{array}$ & & 2 & & & & & & & & & & & \\
\hline Gomphonema parvulum (Kützing) Kützing & & & & & & & & & & & & 1 & \\
\hline Hantzschia amphioxys (Ehrenberg) Grunow & 2 & 2 & & & & & & & & & & & \\
\hline
\end{tabular}


Table 3. Cont.

\begin{tabular}{|c|c|c|c|c|c|c|c|c|c|c|c|c|c|}
\hline \multirow{2}{*}{ Taxa } & \multicolumn{4}{|c|}{ Mutnovsky Volcano } & \multicolumn{9}{|c|}{ Gorely Volcano } \\
\hline & K1 & K2 & K3 & K4 & K5 & K6 & K7 & K8 & K9 & K10 & K11 & K12 & K13 \\
\hline $\begin{array}{l}\text { Humidophila contenta (Grunow) R.L.Lowe, } \\
\text { Kociolek, J.R.Johansen, Van de Vijver, } \\
\text { Lange-Bertalot and Kopalová }\end{array}$ & & 15 & 1 & & & & & & & & & & \\
\hline Luticola mutica (Kützing) D.G.Mann & & 6 & 1 & 5 & & & & & & & & & \\
\hline $\begin{array}{c}\text { Muelleria gibbula (Cleve) S.A. Spaulding et } \\
\text { E.F. Stoermer }\end{array}$ & & 4 & & & & & & & & & & & \\
\hline Navicula cincta (Ehrenberg) Ralfs & & & 3 & & & & & & & & & & \\
\hline Nitzschia cf. ovalis H.J. Arnott & & & & 1 & & & & & & & & & \\
\hline Nitzschia palea (Kützing) W.Smith & 4 & & & & & & & & & & & & \\
\hline Pinnularia borealis Ehrenberg & & 15 & & 4 & 1 & & & & & & 15 & & \\
\hline Pinnularia intermedia (Lagerstedt) Cleve & & 2 & & 1 & & & & & & & & 1 & \\
\hline Pinnularia microstauron (Ehrenberg) Cleve & 1 & & & & 1 & & & & & & & 1 & \\
\hline Pinnularia cf.subcapitata W. Gregory & 7 & 7 & 2 & 1 & 1 & & & & 1 & 2 & 12 & & \\
\hline Pinnularia sp.1 & & 1 & & & & & & & & & & & \\
\hline Pinnularia sp.2 & & & & 1 & & & & & & & & & \\
\hline Pinnularia sp.3 & & & & & & & & & & & 3 & & \\
\hline $\begin{array}{c}\text { Planothidium lanceolatum (Brébisson ex } \\
\text { Kützing) Lange-Bertalot }\end{array}$ & & & & 1 & & & & & & & & & \\
\hline $\begin{array}{l}\text { Platessa oblongella (Østrup) C.E. Wetzel, } \\
\text { Lange-Bertalot et Ector }\end{array}$ & 1 & 2 & & & & & & & & & & & \\
\hline $\begin{array}{c}\text { Psammothidium ventrale (Krasske) } \\
\text { Bukhtiyarova et Round }\end{array}$ & & 4 & & & & & & & & & & & \\
\hline Sellaphora bacillum (Ehrenberg) D.G.Mann & & 1 & & & & & & & & & & & \\
\hline Sellaphora mutata (Krasske) Lange-Bertalot & 1 & 1 & & & & & & & & & & & \\
\hline Sellaphora pupula (Kützing) Mereschkovsky & & 1 & & & & & & & & & & & \\
\hline $\begin{array}{c}\text { Sellaphora submuralis (Hustedt) C.E.Wetzel, } \\
\text { L.Ector, B.Van de Vijver, Compère et D.G. } \\
\text { Mann }\end{array}$ & 1 & & & & & & & & & & & & \\
\hline Stauroneis anceps Ehrenberg & & & & 1 & & & & & & & & & \\
\hline $\begin{array}{l}\text { Staurosirella pinnata (Ehrenberg) } \\
\text { D.M.Williams et Round }\end{array}$ & 3 & 10 & & & & & & & & & & & \\
\hline $\begin{array}{l}\text { Tabularia fasciculata (C. Agardh) D.M. } \\
\text { Williams et Round }\end{array}$ & & & & & & & & & & & 1 & & \\
\hline Total number & 13 & 22 & 5 & 9 & 4 & 0 & 0 & 0 & 1 & 1 & 7 & 3 & 1 \\
\hline
\end{tabular}

Note. The numbers indicate the abundance points.

Soils of the Mutnovsky volcano were more diverse in diatoms in comparison with those of the Gorely volcano. In samples from the Mutnovsky volcano, 35 taxa $(94.6 \%)$ were identified, and only 9 taxa (24.3\%) were found at the Gorely volcano (Table 2, Figure 4). Pinnularia borealis (Figure 3N) were dominant in the soils of both studied volcanoes. At the Mutnovsky volcano, Eunotia curtagrunowii (Figure 3F) and Humidophila contenta (Figure 3J) dominated; in soils of the Gorely volcano, Caloneis bacillum (Figure 3C) prevailed. Only six taxa-Caloneis bacillum, Eunotia curtagrunowii, Pinnularia borealis, P. intermedia, P. microstauron, P. cf. subcapitata-were found in both volcano soils (Table 3, Figure 4). Therefore, the floristic similarity between diatom floras of Mutnovsky and Gorely volcanic soils according to the Sørensen-Czekanowski coefficient was very low, at only $27.9 \%$. 


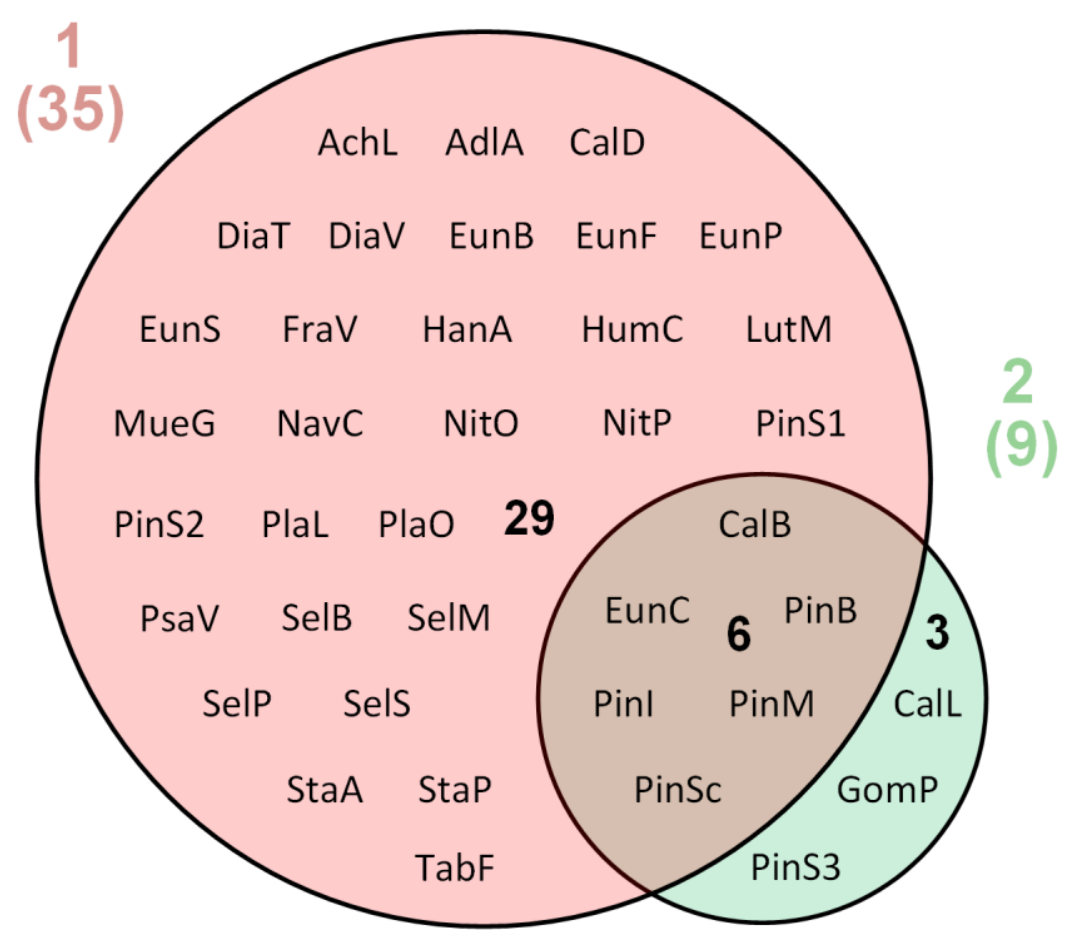

Figure 4. The similarities between diatom communities from the volcano soil studied. 1 (pink circle)Mutnovsky volcano soil community, 2 (green circle)-Gorely volcano soil community. Numbers in brackets indicates the numbers of species in communities. Species abbreviations: AchL-Achnanthes linearis var. pusilla; AdlA-Adlafia aquaeductae; CalB-Caloneis bacillum; CalL-C. lancettula; CalD— C. dubia; DiaT-Diatoma tenuis; DiaV-D. vulgaris; EunB-Eunotia bilunaris; EunC-E. curtagrunowii; EunF-E. fallax; EP-E. paludosa; EunC-E. sudetica f. minor; FraV-Fragilariforma virescens var. exigua; GomP-Gomphonella parvulum; HanA—Hantzschia amphioxys; HumC—Humidophila contenta; LutM-Luticola mutica; MueG-Muelleria gibbula; NavC—Navicula cincta; NitO-Nitzschia cf.ovalis; NitP-N. palea; PinB-Pinnularia borealis; PinI-P. intermedia; PinM-P. microstauron; PinSc-P. cf. subcapitata; PinS1-Pinnularia sp.1; PinS2-Pinnularia sp.2; PinS3_Pinnularia sp.3; PlaL_Planothidium lanceolatum; PlaO_Platessa oblongella; PsaV_Psammothidium ventrale; SelB_Sellaphora bacillum; SelMS. mutata; SelP-S. pupula; SelS—S. submuralis; StaA-Stauroneis anceps; StaP-Staurosirella pinnata; TabF-Tabularia fasciculata.

The diatoms in the studied habitats are adapted to living conditions not only in terrestrial but also in aquatic ecosystems and include bottom, littoral, and epiphytic species, as well as transitional forms: littoral-epiphytic, plankton-bottom, and bottomepiphytic (Table A1). In total, 21 taxa were benthic (56.7\%). Transitional forms of benthic forms (plankton-benthic and benthic-epiphytic) were found for five species (13.5\%). Epiphytic forms were represented by seven species $(18.9 \%)$, while littoral was represented by one species Staurosirella pinnata. The littoral-epiphytic group included four species (10.8\%): Eunotia bilunaris, E. curtagrunowii, Fragilariforma virescens var. exigua, and Tabularia fasciculata (Figure $3 \mathrm{~W}$ ). Bottom-epiphytic forms were also represented by four species (10.8\%): Diatoma vulgaris, Humidophila contenta, Luticola mutica (Figure 3K), and Navicula cincta. Plankton-bottom species were represented by only one representative of diatoms: Diatoma tenuis.

Concerning mineralization, four ecological groups were found: indifferent, halophilic, halophobic, and mesagolob diatoms (Table A1). The largest group (22 species, 59.4\%) was represented by indifferent species. The halophobic group included eight species $(21.6 \%)$ : Caloneis dubia (Figure 3D), Eunotia bilunaris, E. curtagrunowii, E. fallax, E. paludosa, E. sudetica f. minor, Pinnularia cf. subcapitata (Figure 3R), and Platessa oblongella (Table A1). Halophilic taxa were represented by seven species $(19 \%)$ inhabiting slightly salted substrates: $A d-$ lafia aquaeductae (Figure 3B), Diatoma tenuis, Luticola mutica, Navicula cincta, Sellaphora 
mutata, S. pupula, and Staurosirella pinnata. One species of diatoms (2.7\%) belonging to the mesohalobes-Tabularia fasciculata - was found.

Despite the fact that the studied volcanic soils were acidic and slightly acidic, a predominance of taxa that were indifferent to $\mathrm{pH}$ was detected (Table A1). In total, 15 indifferent species (40.5\%), such as Adlafia aquaeductae, Fragilariforma virescens var. exigua, Gomphonema parvulum (Figure 3H), Pinnularia intermedia (Figure 3O), Pinnularia microstauron, and several representatives of the genus Caloneis were detected. Alkaliphiles accounted for $37.3 \%$ of the total number of taxa, including Caloneis lancettula (Figure 3E), Diatoma tenuis, Hantzschia amphioxys (Figure 3I), Humidophila contenta, Luticola mutica, Nitzschia palea (Figure 3M), Pinnularia intermedia, Staurosirella pinnata, and others. Acidophilic taxa were represented by Eunotia bilunaris, E. curtagrunowii, E. fallax (Figure 3G), E. paludosa, E. sudetica f. minor, Pinnularia borealis, and Pinnularia cf. subcapitata. Two alkalibionts, Nitzschia cf. ovalis (Figure 3L) and Diatoma vulgaris, were also noted.

The geographic structure of the diatom communities of the studied volcanic soils also has its peculiarities. The most widespread communities were the cosmopolitan species (31 species and intraspecific taxa), and the arcto-alpine species were represented by 5 taxa (Eunotia curtagrunowii, E. paludosa, E. sudetica f. minor, Fragilariforma virescens var. exigua, Pinnularia intermedia). Boreal species were represented by only two species: Psammothidium ventrale (Figure 3U) and Sellaphora submuralis (Table A1).

\section{Discussion}

We revealed an increase in the number of diatom species with the distance from the volcano craters and with the appearance of primary soil and higher plant vegetation (Tables 2 and 3). Therefore, the studied samples of volcanic substrates located closer to the crater were either sterile or had a poor species diversity; for example, samples K6, K7, $\mathrm{K} 8, \mathrm{~K} 9, \mathrm{~K} 10$ (Tables 2 and 3). In the samples K1, K2, K 9, and K11, an increased number of species was observed (Table 3 ). It is necessary to note that diatom algae are important for the colonization of areas of the Earth's surface after volcanic eruptions [4]. The volcano represents the model of restoration of bare substrates and soil-forming processes [84], where the crater of the volcano is the first stage of succession. The positive interactions between high plants and microorganisms have been discussed in several publications. Plants positively influence microbial communities and carbon accumulation in soils [84,85]. In turn, many groups of prokaryotic [84,86-91] and eukaryotic microorganisms [92-94], including diatom algae, are very important in soil formation and functioning.

Soils at the Gorely volcano were particularly poor regarding diatoms, with only nine taxa found here (Table 3, Figure 4). This may be a consequence of several factors. The samples were collected from the Gorely volcano in August 2010 during eruptive activity in sites K12 and K13 (Table 2). Possibly, the toxicity of the volcanic soils of the Gorely volcano were much higher after the eruption, which also contributed to the small number of diatom species in the soil.

Interestingly, only three taxa were specific for the Gorely volcano soils (Table 3, Figure 4): Caloneis lancettula, Gomphonella parvulum, and Pinnularia sp.3. Possibly, these species are very resistant and can establish the first stage of succession during the restoration of volcanic substrates. In the last decade, new data about the ecology of many terrestrial diatoms have been discussed $[70,79,95,96]$. It should be stressed that our knowledge about the ecological behavior of terrestrial diatom taxa is very limited. For example, in freshwater habitats, Caloneis lancettula was reported as a very sensitive taxon, but it was abundant in disturbed soils in the Attert River basin in Luxembourg [79]. Our study confirms that this species is very adaptive to extreme environmental conditions in terrestrial habitats.

As mentioned above, at the Mutnovsky volcano, the processes of ecosystem restoration, expressed as an increase in the soil fertility and the appearance of bushes and alder forests, were observed. Therefore, in the soils of the Mutnovsky volcano, a greater number of species (29) was found in comparison with the Gorely volcano. At site K2, the maximal number of taxa (22) was detected. The high number of diatoms found here was likely due 
to the formation of "true" soil, more stable soil humidity (Table 2), interactions with high plants, and other factors, influenced by the late stage of volcanic substrate restoration [84].

The formation of the species composition of diatoms is probably influenced by the accidental transfer of cells from nearby regions. For example, Navicula sp. and Nitzschia sp. were the most common airborne algae [97].

The local selection of species to the physicochemical conditions of volcano soils is also very important. The $\mathrm{pH}$ of the soil influenced species abundance. Basically, samples K1-K4 with alkaline soils were more diverse in terms of diatoms in comparison with the samples with acidic soil; for example, K8-K10, K12, and K13. Most organisms live at a pH of 4 to 9 , and their optimal growth is observed in an environment close to neutral. At the same time, diatoms are tolerant of extreme $\mathrm{pH}$ [79]. The $\mathrm{pH}$ has an indirect effect through the solubility of various substances and their accessibility to algae. With an increase in the acidity of the environment, there is a difficulty in the flow of nitrogen, phosphorus, and other mineral elements into the diatom cells. This explains the abundant development of diatoms in neutral and alkaline soils. The acidic reaction of the environment also negatively affects the morphology of diatoms. Perhaps this is the reason why the diversity and abundance of diatoms in soil samples with alkaline volcanic soils increased.

The geology of a volcanic substrate can also influence the species compositions of diatoms [70]. Volcanic rocks of Mutnovsky and Gorely are rich in $\mathrm{SiO}_{2}$ and other elements, such as $\mathrm{Al}, \mathrm{Fe}, \mathrm{Si}$, and $\mathrm{Mg}$ (Table 1). Algae contribute to the dissolving of silicate minerals by aiding in the retention of water and acidification by excreting carbonic acid [98]. As a result of exposure to physicochemical and biological factors, insoluble minerals transform into soluble forms. These inorganic nutrients are very important for physiology and biochemistry and promote the survival of diatoms [99-103]. High concentrations of nutrients can positively influence the diatoms on the volcanic substrate at the early stage of the colonization of lifeless substrates after an eruption. On another side, in the primary stages of succession on volcanic substrate, diatoms lack enough moisture and organic nutrients. This circumstance prevents their abundant development.

We observed a relatively low diversity of diatoms in Mutnovsky and Gorely volcano soils in comparison with other types of soils [79,104-106]. This phenomenon could be explained by the very low density, high hydrophilicity, and high filtration capacity of volcanic soils. Such soils resemble a "sponge" through which water easily seeps without lingering in it. Diatoms are called "genuine soil-building algae" and can be underestimated due to their invisibility on the surface [12].

It is important to note that, despite the prevalence of taxa indifferent to $\mathrm{pH}$ in total, the heterogeneity of ecological characteristics of species in different sites was observed. For the site K2 at the base of the Mutnovsky volcano, with alder forest and humus-ocher soils (Tables 2, 3 and A1), acidophilic taxa Eunotia curtagrunowii and Pinnularia borealis together with alkaliphilic Humidophila contenta were dominant. The frequent occurrence of the genus Humidophila in terrestrial ecosystems characterized by insufficient moisture possibly is a consequence of the morphology of the taxon. The reduced external openings of the Humidophila frustules allow a reduction in the moisture loss [70].

Some taxa were recorded before in Kamchatka volcanic soil. Pinnularia borealis and Hantzscia amphioxys were detected in the volcanic soil of the Golovina volcano in Kamchatka [5]. Hantzschia amphioxys, Humidophila contenta, and Pinnularia subcapitata were recorded in volcano soils of the Kuril Islands, which also belong to the Kuril-Kamchatka Island Arc [107]. The genus Humidophila has been recorded in freshwater habitats on the islands of Hawai'i, known for their volcanic activity [108]. Representatives of the genus Navicula were detected in the outermost part of the Kilau Iki volcano in soil substrate in the periphery of the cinder cone without much destruction during the eruption and in the transitional zone with destroyed vegetation [13]. Several species from Mutnovsky and Gorely volcano soils were recorded in soils of the Malki, Upper Paratunka, and Dachnie thermal springs: Caloneis lancettula, Eunotia curtagrunowii, Navicula cincta, Pinnularia borealis, 
P. microstauron, P. cf. subcapitata, and Planothidium lanceolatum [28]. This species might be considered as a typical Mutnovsky geothermal field diatom community.

In Mutnovsky and Gorely volcano soils, we found mostly small-sized species, such as Caloneis bacillum, Humidophila contenta, and Eunotia curtagrunowii (Figure 3). The results obtained once again confirm the hypothesis that small diatoms dominate in aerial communities [95].

A comparison of the diatom communities of volcano soils of Kamchatka with volcano soil of other regions reveals interesting peculiarities. In algal communities on an Antarctic active volcano on Deception Island, South Shetlands, diatoms were dominant together with cyanobacteria [15]. The species composition of diatoms in this region has some similarities with the diatoms of Mutnovsky and Gorely volcano soils; for example, the wide distribution of Pinnularia genus and presence of Hantzschia amphioxys, Luticola mutica, Nitzschia, and Muelleria genera. A wide distribution of cosmopolitan ("ubiquitous") species with a high range of ecological plasticity, discussed in previous studies $[5,15]$, might be a specific feature of volcanic soils.

However, there were significant differences in Kamchatka's investigated volcano soil diatoms communities: the presence of genera Eunotia and Caloneis with the domination of some species from these genera; the prevalence of Humidophila contenta; the existence of genera Diatoma and Sellaphora; and some cosmopolitan species, such as Adlafia aquaeductae, Gomphonema parvulum, Planothidium lanceolatum (Figure 3S), and others.

It should be noted that many diatoms in our study, especially cosmopolitan diatoms, could be new taxa or cryptic species. Cosmopolitan and wide-distributed taxa, such as Pinnularia borealis, Hantzschia amphioxys, and Humidophila contenta, are cryptic or pseudocryptic $[96,109]$. To understand the biodiversity of this unique habitat better, further research using electron microscopy and molecular genetic tools is needed.

Thus, the diatom flora of Mutnovsky and Gorely volcano soils in the Kamchatka peninsula includes mostly cosmopolitan small-sized taxa that are adapted to survival in conditions of the toxic substrate with limited moisture and organic matter. These data once again confirm the high adaptive potential of diatom algae and add new knowledge about the ecology and biogeography of this group of microorganisms.

Author Contributions: Conceptualization, A.F. and L.G.; methodology, A.F.; software, Y.G.; validation, A.F. and L.G.; formal analysis, A.F. and Y.G.; investigation, A.F.; resources, L.G.; data curation, A.F., Y.G. and R.A.; writing—original draft preparation, A.F. and R.A.; writing — review and editing, L.G.; visualization, Y.G.; supervision, L.G.; project administration, L.G.; funding acquisition, L.G. All authors have read and agreed to the published version of the manuscript.

Funding: The reported study was funded by the Russian Foundation for Basic Research, project number 20-04-00814 a.

Data Availability Statement: Not applicable.

Acknowledgments: The authors are very thankful to A.A. Gontcharov (Federal Scientific Center of the East Asia Terrestrial Biodiversity) for samples and valuable discussions.

Conflicts of Interest: The authors declare no conflict of interest. 


\section{Appendix A}

Table A1. List of diatom taxa with the relative abundance and ecological preferences * [71-79] in the volcanic soils of Mutnovsky and Gorely volcanoes.

\begin{tabular}{|c|c|c|c|c|c|c|c|}
\hline Taxon & 1 & 2 & Habitat * & $\begin{array}{c}\text { Salinity } \\
\text { Tolerance * }\end{array}$ & $\mathrm{pH}^{*}$ & Distribution * & Ecological Group * \\
\hline $\begin{array}{c}\text { Achnanthes linearis var. pusilla } \\
\text { Grunow }\end{array}$ & 2 & & Ep & $\mathrm{i}$ & al & c & Freshwater \\
\hline $\begin{array}{c}\text { Adlafia aquaeductae (Krasske) } \\
\text { Lange-Bertalot }\end{array}$ & 3 & & B & hl & $\mathrm{i}$ & c & Freshwater \\
\hline $\begin{array}{l}\text { Caloneis bacillum (Grunow) } \\
\text { Cleve }\end{array}$ & 6 & 15 & B & $\mathrm{i}$ & $\mathrm{i}$ & c & $\begin{array}{c}\text { Marine, brackish, } \\
\text { freshwater, terrestrial }\end{array}$ \\
\hline Caloneis dubia Krammer & 1 & & B & $\mathrm{hb}$ & $\mathrm{i}$ & c & Freshwater \\
\hline $\begin{array}{l}\text { Caloneis lancettula (Schulz) } \\
\text { Lange-Bertalot et Witkowski }\end{array}$ & & 1 & B & $\mathrm{i}$ & al & c & Freshwater, terrestrial \\
\hline Diatoma tenuis Agardh & 3 & & P B & $\mathrm{hl}$ & al & c & Freshwater \\
\hline Diatoma vulgaris Bory & 1 & & B Ep & $\mathrm{i}$ & alb & c & Freshwater \\
\hline $\begin{array}{c}\text { Eunotia bilunaris (Ehrenberg) } \\
\text { Schaarschmidt }\end{array}$ & 1 & & L Ep & $\mathrm{hb}$ & ac & c & Freshwater \\
\hline $\begin{array}{l}\text { Eunotia curtagrunowii } \\
\text { Nörpel-Schempp et } \\
\text { Lange-Bertalot }\end{array}$ & 15 & 1 & L Ep & $\mathrm{hb}$ & ac & aа & Freshwater \\
\hline Eunotia fallax A. Cleve & 10 & & Ep & $\mathrm{hb}$ & ac & c & Freshwater \\
\hline Eunotia paludosa Grunow & 2 & & Ep & $\mathrm{hb}$ & ac & aa & Freshwater \\
\hline $\begin{array}{c}\text { Eunotia sudetica f. minor } \\
\text { Manguin in Bourrelly et } \\
\text { Manguin }\end{array}$ & 3 & & Ep & $\mathrm{hb}$ & ac & aа & Freshwater \\
\hline $\begin{array}{l}\text { Fragilariforma virescens var. } \\
\text { exigua (Grunow) M.Poulin }\end{array}$ & 2 & & L Ep & $\mathrm{i}$ & $\mathrm{i}$ & aa & Freshwater \\
\hline $\begin{array}{c}\text { Gomphonema parvulum (Kützing) } \\
\text { Kützing }\end{array}$ & & 1 & Ep & $\mathrm{i}$ & $\mathrm{i}$ & c & Marine, freshwater \\
\hline $\begin{array}{l}\text { Hantzschia amphioxys } \\
\text { (Ehrenberg) Grunow }\end{array}$ & 2 & & B & $\mathrm{i}$ & al & c & $\begin{array}{l}\text { Marine, freshwater, } \\
\text { terrestrial }\end{array}$ \\
\hline $\begin{array}{c}\text { Humidophila contenta (Grunow) } \\
\text { R.L.Lowe, Kociolek, } \\
\text { J.R.Johansen, Van de Vijver, } \\
\text { Lange-Bertalot et Kopalová }\end{array}$ & 15 & & B Ep & $\mathrm{i}$ & al & c & Freshwater, terrestrial \\
\hline $\begin{array}{l}\text { Luticola mutica (Kützing) } \\
\text { D.G.Mann }\end{array}$ & 6 & & B Ep & hl & al & c & Freshwater, terrestrial \\
\hline $\begin{array}{l}\text { Muelleria gibbula (Cleve) S.A. } \\
\text { Spaulding et E.F. Stoermer }\end{array}$ & 4 & & B & $\mathrm{i}$ & al & c & Freshwater \\
\hline $\begin{array}{l}\text { Navicula cincta (Ehrenberg) } \\
\text { Ralfs }\end{array}$ & 3 & & B Ep & hl & al & c & $\begin{array}{c}\text { Brackish, freshwater, } \\
\text { terrestrial }\end{array}$ \\
\hline Nitzschia cf. ovalis H.J.Arnott & 1 & & $\mathrm{~B}$ & $\mathrm{i}$ & alb & c & $\begin{array}{c}\text { Marine, brackish, } \\
\text { freshwater, terrestrial }\end{array}$ \\
\hline $\begin{array}{c}\text { Nitzschia palea (Kützing) } \\
\text { W.Smith }\end{array}$ & 4 & & B & $\mathrm{i}$ & al & c & Freshwater \\
\hline Pinnularia borealis Ehrenberg & 15 & 15 & B & $\mathrm{i}$ & ac & c & Freshwater, terrestrial \\
\hline
\end{tabular}


Table A1. Cont.

\begin{tabular}{|c|c|c|c|c|c|c|c|}
\hline Taxon & 1 & 2 & Habitat * & $\begin{array}{c}\text { Salinity } \\
\text { Tolerance * }\end{array}$ & $\mathrm{pH}^{*}$ & Distribution * & Ecological Group * \\
\hline $\begin{array}{l}\text { Pinnularia intermedia } \\
\text { (Lagerstedt) Cleve }\end{array}$ & 2 & 1 & B & $\mathrm{i}$ & al & aa & Freshwater \\
\hline $\begin{array}{l}\text { Pinnularia microstauron } \\
\text { (Ehrenberg) Cleve }\end{array}$ & 1 & 2 & B & $\mathrm{i}$ & $\mathrm{i}$ & c & Freshwater, terrestrial \\
\hline $\begin{array}{c}\text { Pinnularia cf. subcapitata W. } \\
\text { Gregory }\end{array}$ & 7 & 12 & B & $\mathrm{hb}$ & ac & c & Freshwater, terrestrial \\
\hline Pinnularia sp1. & 1 & & B & $\mathrm{i}$ & $\mathrm{i}$ & c & $\begin{array}{c}\text { Marine, brackish, } \\
\text { freshwater, terrestrial }\end{array}$ \\
\hline Pinnularia sp.2 & 1 & & B & $\mathrm{i}$ & $\mathrm{i}$ & c & $\begin{array}{c}\text { Marine, brackish, } \\
\text { freshwater, terrestrial }\end{array}$ \\
\hline Pinnularia sp.3 & & 3 & B & $\mathrm{i}$ & $\mathrm{i}$ & c & $\begin{array}{c}\text { Marine, brackish, } \\
\text { freshwater, terrestrial }\end{array}$ \\
\hline $\begin{array}{c}\text { Planothidium lanceolatum } \\
\text { (Brébisson ex Kützing) } \\
\text { Lange-Bertalot }\end{array}$ & 1 & & Ep & $\mathrm{i}$ & al & c & Freshwater, terrestrial \\
\hline $\begin{array}{c}\text { Platessa oblongella (Østrup) } \\
\text { C.E.Wetzel, Lange-Bertalot and } \\
\text { Ector }\end{array}$ & 2 & & Ep & $\mathrm{hb}$ & $\mathrm{i}$ & c & Freshwater \\
\hline $\begin{array}{c}\text { Psammothidium ventrale } \\
\text { (Krasske) Bukhtiyarova and } \\
\text { Round }\end{array}$ & 4 & & B & $\mathrm{i}$ & $\mathrm{i}$ & $\mathrm{b}$ & Freshwater \\
\hline $\begin{array}{l}\text { Sellaphora bacillum (Ehrenberg) } \\
\text { D.G.Mann }\end{array}$ & 1 & & B & $\mathrm{i}$ & al & c & Freshwater \\
\hline $\begin{array}{c}\text { Sellaphora mutata (Krasske) } \\
\text { Lange-Bertalot }\end{array}$ & 1 & & B & hl & $\mathrm{i}$ & c & Freshwater \\
\hline $\begin{array}{c}\text { Sellaphora pupula (Kützing) } \\
\text { Mereschkovsky }\end{array}$ & 3 & & B & hl & $\mathrm{i}$ & c & Freshwater \\
\hline $\begin{array}{l}\text { Sellaphora submuralis (Hustedt) } \\
\text { C.E.Wetzel, L.Ector, B.Van de } \\
\text { Vijver, Compère et D.G.Mann }\end{array}$ & 1 & & B & $\mathrm{i}$ & $\mathrm{i}$ & $\mathrm{b}$ & Freshwater \\
\hline Stauroneis anceps Ehrenberg & 1 & & B & $\mathrm{i}$ & $\mathrm{i}$ & c & Freshwater \\
\hline $\begin{array}{l}\text { Staurosirella pinnata (Ehrenberg) } \\
\text { D.M.Williams et Round }\end{array}$ & 10 & & $\mathrm{~L}$ & hl & al & c & Marine, freshwater \\
\hline $\begin{array}{l}\text { Tabularia fasciculata (C.Agardh) } \\
\text { D.M.Williams et Round }\end{array}$ & 1 & & Ep L & $\mathrm{mh}$ & al & c & $\begin{array}{l}\text { Marine, brackish, } \\
\text { freshwater }\end{array}$ \\
\hline 37 & 35 & 9 & & & & & \\
\hline
\end{tabular}

Notes. 1-Mutnovsky, 2-Gorely; Habitat: P-planktonic, B-benthic, L-littoral, Ep-epiphytic; Salinity tolerance: i-indifferent, $\mathrm{hb}$-halophobic, hl一halophilic, $\mathrm{mh}$-mesogalob; $\mathrm{pH}$ (relation to $\mathrm{pH}$ ): i-indifferent, ac—acidophilic, al—alkaliphilic, alb—alkalibiont; Distribution: aa—arcto-alpine, $\mathrm{b}$ - boreal, $\mathrm{c}$-cosmopolitan. * data from the literature.

\section{References}

1. Dingwell, D.B.; Lavallée, Y.; Kueppers, U. Volcanic ash: A primary agent in the Earth system. Phys. Chem. Earth 2012, 45-46, 2-4. [CrossRef]

2. Crisafulli, C.M.; Swanson, F.J.; Halvorson, J.J.; Clarkson, B.D. Volcano ecology: Disturbance characteristics and assembly of biological communities. In The Encyclopedia of Volcanoes, 2nd ed.; Sigurdsson, H., Houghton, B., McNutt, S., Rymer, H., Stix, J., Eds.; Academic Press: Cambridge, MA, USA, 2015; pp. 1265-1284.

3. Schwabe, G.H. Blue-green algae as pioneers on post-volcanic substrate (Surtsey/Iceland). In Proceedings of the First International Symposium on Taxonomy and Biology of Blue-green Algae, Madras, India, 8-13 January 1972; pp. 419-424.

4. Schwabe, G.H. Nitrogen fixing blue-green algae as pioneer plants on Surtsey 1968-1973. Surtsey Res. Progr. Rep. 1974, 7, $22-25$.

5. Shtina, E.A.; Andreyeva, V.M.; Kuzyakina, T.I. Algae settlement of volcanic substrates. Botanicheskiy Zhurnal $1992,8,33-42$. 
6. Treub, M. Notice sur la nouvelle flore de Krakatau. Annales du Jardin Botanique de Buitenzorg 1888, 7, $213-223$.

7. Schwabe, G.H. On the algal settlement in craters on Surtsey during summer 1968. Surtsey Res. Progr. Rep. 1970, 5, 51-55.

8. Schwabe, G.H.; Behre, K. Ökogenese der Insel Surtsey 1968-1970. Naturwiss. Rundschau. 1971, 24, 513-519.

9. Henriksson, E. Algal nitrogen fixation in temperate regions. Plant Soil 1971, 35, 415-419. [CrossRef]

10. Henriksson, L.E.; Enekell, P.H.; Henriksson, E. Determination of the nitrogen-fixing capacity of algae in soil. Oikos 1972, 23, 420-423. [CrossRef]

11. Brock, T.D. Primary colonization of Surtsey, with special reference to the blue-green algae. Oikos 1973, 24, 239-243. [CrossRef]

12. Behre, K.; Schwabe, G.H. Auf Surtsey/Island im Sommer 1968 Nachgewiesene nicht Marine Algen; Schriften Natturwiss Vereins: Schleswig, Germany, 1970; pp. 31-100, Sonderband.

13. Carson, J.L.; Brown, R.M. Studies of Hawaiian freshwater and soil algae II. Algal colonization and succession on a dated volcanic substrate. J. Phycol. 1978, 14, 171-178. [CrossRef]

14. Bölter, M.; Blume, H.P.; Kuhn, D. Soils and their microbiological properties from a transect from Cape Horn to the Antarctic Peninsula. Polar Biosci. 1999, 12, 54-67.

15. Fermani, P.; Mataloni, G.; de Vijver, B.V. Soil microalgal communities on an Antarctic active volcano (Deception Island, South Shetlands). Polar Biol. 2007, 30, 1381-1393. [CrossRef]

16. Pimenov, E.P. Function of Microorganism Complexes of in the Intensive Volcanic Ashfall Zone. Ph.D. Thesis, Institute of Mikrobiology and Virollogy of Akademy Nauk of KazSSR, Alma-Ata, Kazakhstan, 1983.

17. Kuzyakina, T.I. Transformation of volcanic ash by microorganisms. In Volcanism and Associated Processes; Dalnauka: PetropavlovskKamchatski, Russia, 1985; pp. 232-234.

18. Nanzyo, M. Unique properties of volcanic ash soils. Global environmental research. Assoc. Int. Res. Initiat. Environ. Stud. 2002, 6, 99-112.

19. $\mathrm{Hu}, \mathrm{C} . ; \mathrm{Gao}, \mathrm{K} . ;$ Whitton, B.A. Semi-Arid regions and deserts. In Ecology of Cyanobacteria II: Their Diversity in Space and Time, 2nd ed.; Whitton, B.A., Ed.; Springer: Berlin/Heidelberg, Germany, 2012; pp. 345-369.

20. Cuadros, J.; Spiro, B.; Dubbin, W.; Jadubansa, P. Rapid microbial stabilization of unconsolidated sediment against wind erosion and dust generation. J. Soils Sediments 2010, 10, 1415-1426. [CrossRef]

21. Larionov, I.A.; Marapulets, Y.V.; Shevtsov, B.M. Features of the earth surface deformations in the Kamchatka peninsula and their relation to geoacoustic emission. Solid Earth 2014, 5, 1293-1300. [CrossRef]

22. Levin, V.; Droznina, S.; Gavrilenko, M.; Carr, M.J.; Senyukov, S. Seismically active subcrustal magma source of the Klyuchevskoy volcano in Kamchatka, Russia. Geology 2014, 42, 983-986. [CrossRef]

23. Marapulets, Y.; Rulenko, O. Joint anomalies of high-frequency geoacoustic emission and atmospheric electric field by the ground-atmosphere boundary in a seismically active region (Kamchatka). Atmosphere 2019, 10, 267. [CrossRef]

24. White, J.D.L.; Houghton, B.F. Primary volcaniclastic rocks. Geology 2006, 34, 677-680. [CrossRef]

25. Kalitina, E.G.; Nikulina, T.V.; Kharitonova, N.A.; Wah, E.A. Materials for the study of the diversity of microorganisms in the thermal springs of Kamchatka (Russia). In Proceedings of the All Russian Conference with International Participation "Modern Problems of Hydrogeology, Engineering Geology and Hydrogeoecology Eurasia" with Elements of a Scientific School, Tomsk, Russia, 23-27 November 2015; pp. 510-513. (In Russian).

26. Nikulina, T.V.; Kalitina, E.G.; Vakh, E.A.; Kharitonova, N.A. List of diatoms from three hot springs from Kamchatka-Malkinskiye, Nachikinskiye and Verhne-Paratunskiye (Russia). In Freshwater Life; Bogatov, V.V., Ed.; Dalnauka: Vladivostok, Russia, 2016; Volume 2, pp. 108-115. (In Russian)

27. Nikulina, T.V.; Grishchenko, O.V. Diatom flora of Dachnye Thermal Springs (Kamchatka Peninsula, Russia). In Vladimir Yakovlevic Levanidov's Biennial Memorial Meetings; FNC Bioraznobrazia: Vladivostok, Russia, 2017; Volume 7, pp. 185-193. (In Russian)

28. Fazlutdinova, A.I.; Gabidullin, Y.Z.; Allaguvatova, R.Z.; Gaysina, L.A. Diatoms in Kamchatka's Hot Spring Soils. Diversity 2020, 12, 435. [CrossRef]

29. Kuzyakina, T.I. Ecology and Geochemical Activity of Microorganisms on Active Volcanoes and Hydrothermal Waters (Kunashir Island, Kuril Islands Kamchatka); Dalnauka: Vladivostok, Russia, 2004; pp. 1-251.

30. Abdullin, S. Cyanobacteriae and algae of lava tubes in Kamchatka, Russia. Cave Karst Sci. 2013, 40, 141-144.

31. Chashchin, A.A.; Martynov, Y.A.; Perepelov, A.B.; Ekimova, N.I.; Vladimirova, T.P. Physical and chemical conditions of the formation and evolution of late pleistocene-holocene magmas of the Gorely and Mutnovsky volcanoes, southern Kamchatka. Russ. J. Pac. Geol. 2011, 5, 348-367. [CrossRef]

32. Calabrese, S.; Scaglione, S.; D'Alessandro, W.; Brusca, L.; Bellomo, S.; Parello, F. A literature review and new data of trace metals fluxes from worldwide active volcanoes. In Miscelanea INGV, Proceedings of the Conferenza, A. Rittmann, Nicolosi, Catania, Italy, 12-14 December 2012; Corsaro, R.A., Ed.; Istituto Nazionale di Geofisica e Vulcanologia: Catania, Italy, $2012 ;$ pp. 41-42.

33. Duggen, S.; Portnyagin, M.; Baker, J.; Ulfbeck, D.; Hoernle, K.; Garbe-Schönberg, D.; Grassineau, N. Drastic shift in lava geochemistry in the volcanic-front to rear-arc region of the Southern Kamchatkan subduction zone: Evidence for the transition from slab surface dehydration to sediment melting. Geochimica Cosmochimica Acta 2007, 71, 452-480. [CrossRef]

34. Volynets, O.N.; Babanskii, A.D.; Gol'tsman, Y.V. Variations in isotopic and trace-element composition of lavas from volcanoes of the Northern Group, Kamchatka, in relation to specific features of subduction. Geochem. Int. 2000, 38, 974-989.

35. Ishikawa, T.; Tera, F.; Nakazawa, T. Boron isotope and trace element systematics of the three volcanic zones in the Kamchatka arc. Geochimica Cosmochimica Acta 2001, 65, 4523-4537. [CrossRef] 
36. Avdeiko, G.P.; Savelyev, D.P.; Palueva, A.A.; Popruzhenko, S.V. Evolution of the Kurile-Kamchatkan volcanic arcs and dynamics of the Kamchatka-Aleutian Junction. In Volcanism and Subduction: The Kamchatka Region; Geophysical Monograph Series; Eichelberger, J., Ed.; AGU: Washington, DC, USA, 2007; Volume 172, pp. 37-55.

37. Gavrilenko, M.; Ozerov, A.; Kyle, P.R.; Carr, M.J.; Nikulin, A.; Vidito, C.; Danyushevsky, L. Abrupt transition from fractional crystallization to magma mixing at Gorely volcano (Kamchatka) after caldera collapse. Bull. Volcanol. 2016, 78, 47. [CrossRef]

38. Vereina, O.B. Natural state modeling of the Mutnovsky geothermal field, Kamchatka, Russia. In Proceedings of the Geothermal training, Reykjavik, Iceland, 14-17 September 2003; pp. 505-526.

39. Sugrobov, V.M. Geothermal and Geochemical Investigations of High-Temperature Hydrothermal Systems (by the Example of Mutnovsky Geothermal Field); Nauka: Moscow, Russia, 1986; p. 305. (In Russian)

40. Assaulov, S.G. A conceptual model and reservoir assessment for the Mutnovsky geothermal field, Kamchatka, Russia. In Proceedings of the Geothermal Training, Reykjavik, Iceland; 1994; pp. 1-30.

41. Fedotov, S.A.; Ozerov, A.Y.; Magus'kin, M.A. The 1998-2000 Eruption of Karymskii Volcano, the Related Seismic, Geodynamic, and Postvolcanic Processes and Their Impact on the Environment. In Catastrophic Processes and their Impact on the Natural Environment: Volcanism; Laverov, N.P., Ed.; Regional'naya Obshchestvennaya Organizatsiya Uchenykh po Problemam Prikladnoi Geofiziki: Moscow, Russia, 2002; pp. 117-160.

42. Kondratyuk, V.I. Climate of Kamchatka; Hydrometeoizdat: Moscow, Russia, 1974; p. 204. (In Russian)

43. Neshataeva, V.Y. Vegetation of the Kamchatka Peninsula; KMK: Moscow, Russia, 2009; p. 537. (In Russian)

44. Karpachevsky, L.O.; Alyabyina, I.O.; Zakharikhina, L.V.; Makeev, A.O.; Merechek, M.S.; Radyukin, A.Y.U.; Shoba, S.A. Kamchatka Soils; GEOS: Moscow, Russia, 2009; p. 224. (In Russian)

45. Zharikova, E.A. Potential potassium buffer capacity of Kamchatka volcanic soils. Eurasian Soil Sci. 2011, 44, 493-499. [CrossRef]

46. Zakharikhina, L.V.; Litvinenko, Y.S. Geochemical specificity of volcanic soils of Kamchatka. Eurasian Soil Sci. 2011, 43, 380-389. [CrossRef]

47. Sokolov, I.A. Volcanic Activity and Soil Generation (in Kamchatka); Nauka: Moscow, Russia, 1973; p. 224. (In Russian)

48. Neshataeva, V.Y. Vegetable cover of Kamchatka Peninsula and its geobotanical regionalization. Proc. Karelian Res. Cent. RAS 2011, 1, 3-22. (In Russian)

49. Simon, A.; Yogodzinski, G.M.; Robertson, K.; Smith, E.; Selyangin, O.; Kiryukhin, A.; Mulcahy, S.R.; Walker, J.D. Evolution and genesis of volcanic rocks from Mutnovsky Volcano, Kamchatka. J. Volcanol. Geotherm. Res. 2014, 286, 116-137. [CrossRef]

50. Semenov, V.I. the Edge of Hot Springs; Far Eastern Book Publishing House: Petropavlovsk-Kamchatsky, Russia, 1988 ; p. 142. (In Russian)

51. Jakes, P.; Gill, J. Rare earth elements and the island arc tholeiitic series. Earth Planet. Sci. Lett. 1970, 9, 17-28. [CrossRef]

52. Kuznetsov, P.Y.; Koulakov, I.; Jakovlev, A.; Abkadyrov, I.; Deev, E.; Gordeev, E.; Senyukov, S.; El Khrepy, S.; Al Arifi, N. Structure of volatile conduits beneath Gorely Volcano (Kamchatka) revealed by local earthquake tomography. Geosciences 2017, 7, 111. [CrossRef]

53. Selyangin, O.B.; Ponomareva, V.V. Gorelovsky volcanic center, South Kamchatka: Structure and evolution. Volcanol. Seismol. 1999, 21, 163-194.

54. Kirsanov, I.T.; Melekestsev, I.V. Gorely volcano. In Active Volcanoes of Kamchatka; Nauka: Moscow, Russia, 1991; Volume 1, pp. 292-315.

55. Kuznetsov, A.B.; Staricova, E.V.; Maslov, A.V.; Konstantinova, G.V., Sr. Isotopic Chemostratigraphy of Precambrian Carbonate Rocksin the Amderma Rise, Pai-Khoi Ridge. Doklady Earth Sci. 2016, 246, 447-451.

56. Volynets, O.N.; Flerov, G.B.; Khrenov, A.P.; Ermakov, V.A. Volcanic petrology of the Great Tolbachik fissure eruption. Akad. Nauk SSSR Doklady. Earth Sci. Sec. 1976, 238, 179-183.

57. Selyangin, O.B. Structure, substance and near-surface foci of the Mutnovsky and Gorely volcanoes (Mutnovsky geothermal area, Kamchatka. Min. Inf. Anal. Bull. 2016, 31, 348-438. (In Russian)

58. Khrenov, A.; Artemyev, O.; Belousov, A.; Vasiliev, V.; Girina, O.; Gordeev, E.; Dvigalo, V.; Droznin, V.; Demyanchuk, Y.; Dubrovskaya, I.; et al. Volcanoes of Kamchatka and the Kuril islands. Russ. Found. Basic Res. J. 2015, 2, 105.

59. Melekestsev, I.V.; Braytseva, O.K.; Ponomareva, V.V. Dynamics of Activity of Mutnovsky and Gorely volcanoes in Holocene and potential hazard for adjacent regions. Volcanol. Seismol. 1987, 3, 3-18. (In Russian)

60. Barragán, C.; Wetzel, C.E.; Ector, L. A standard method for the routine sampling of terrestrial diatom communities for soil quality assessment. J. Appl. Phycol. 2018, 30, 1095-1113. [CrossRef]

61. Acker, F.; Russell, B.; Morales, E. Preparation of Diatom Slides Using Naphrax ${ }^{\mathrm{TM}}$ Mounting Medium; Protocol P-13-49; Academy of Natural Sciences of Philadelphia: Philadelphia, PA, USA; Patrick Center for Environmental Research: Philadelphia, PA, USA, 1999; pp. 13-42.

62. Krammer, K.; Lange-Bertalot, H. Bacillariophyceae, Naviculaceae. Süßwasserflora von Mitteleuropa. Band 2/1; Spectrum Academiche Verlag: Berlin, Germany, 1986; p. 876.

63. Krammer, K.; Lange-Bertalot, H. Bacillariophyceae, Teil 2. epithemiaceae, bacillariaceae, surirellaceae. In Süsswasserflora von Mitteleuropa; Pascher, A., Ettl, H., Gerloff, J., Heynig, H., Mollenhauer, D., Eds.; VEB Gustav Fisher Verlag: Stuttgart, Germany, 1988; p. 596. 
64. Krammer, K.; Lange-Bertalot, H. Bacillariophyceae, Teil 3. centrales, fragilariaceae, eunotiaceae, achnanthaceae. In Süßwasserflora von Mitteleuropa; Pascher, A., Ettl, H., Gerloff, J., Heynig, H., Mollenhauer, D., Eds.; VEB Gustav Fisher Verlag: Stuttgart, Germany, 1991; p. 576.

65. Krammer, K.; Lange-Bertalot, H. Bacillariophyceae, Teil 4. achnanthaceae, kritische erganzungen zu navicula (Lineolatae) und gomphonema. In Süsswasserfloravon Mitteleuropa; Pascher, A., Ettl, H., Gerloff, J., Heynig, H., Mollenhauer, D., Eds.; VEB Gustav Fisher Verlag: Stuttgart, Germany, 1991; p. 436.

66. Hofmann, G.; Werum, M.; Lange-Bertalot, H. Diatomeen im Süßwasser-Benthos von Mitteleuropa. In Bestimmungsflora Kieselalgen für die Ökologische Praxis. Über 700 der Häufigsten Arten und Ihre Ökologie; Koeltz Scientific Books: Königstein, Germany, 2013; p. 908.

67. Paula, C.F.; Lowe, R.L.; Johansen, J.R. Teratology in Eunotia taxa in The Great Smoky Mountains National Park and description of Eunotia macroglossa spp. nov. Diatom Res. 2009, 24, 273-290.

68. Wetzel, C.E.; Ector, L.; Vijver, B.; Compère, P.; Mann, D.G. Morphology, typification and critical analysis of some ecologically important small naviculoid species (Bacillariophyta). Fottea 2015, 15, 203-234. [CrossRef]

69. Potapova, M.G. Diatoms of Bering Island, Kamchatka, Russia. Nova Hedwigigia 2014, 143, 63-102.

70. Furey, P.C.; Manoylov, K.M.; Lowe, R.L. New and interesting aerial diatom assemblages from southwestern Iceland. Phytotaxa 2020, 428, 173-208. [CrossRef]

71. Ettl, H.; Gärtner, G. Syllabus der Boden-, Luft-und Flechtenalgen; Gustav Fischer Verlag: Stuttgart, Germany, $1995 ;$ p. 721.

72. Kociolek, J.P.; Spaulding, S.A. Eunotioid and asymmetrical naviculoid diatoms. In Freshwater Algae of North America: Ecology and Classification; Wehr, J.D., Sheath, R.G., Eds.; Academic Press: San Diego, CA, USA, 2003; pp. 655-668.

73. Kociolek, J.P.; Spaulding, S.A. Symmetrical naviculoid diatoms. In Freshwater Algae of North America: Ecology and Classification; Wehr, J.D., Sheath, R.G., Eds.; Academic Press: San Diego, CA, USA, 2003; pp. 637-652.

74. Lowe, R.L. Keeled and canalled raphid diatoms. In Freshwater Algae of North America. Ecology and Classification; Wehr, J.D., Sheath, R.G., Eds.; Academic Press: New York, NY, USA, 2003; pp. 669-684.

75. Stoermer, E.F.; Julius, M.L. Centric diatoms. In Freshwater Algae of North America: Ecology and Classification; Wehr, J.D., Sheath, R.G., Eds.; Academic Press: San Diego, CA, USA, 2003; pp. 559-652.

76. Flechtner, V.R.; Johansen, J.R.; Belnap, J. The biological soil crusts of the San Nicolas Island: Enigmatic algae from a geographically isolated ecosystem. West. N. Am. Nat. 2008, 68, 405-436. [CrossRef]

77. Stenina, A.S. Diatoms (Bacillariophyta) in the Lakes of the East of the Bolshezemelskaya Tundra; Institute of Biology Komi Scientific Center, Ural Branch of the Russian Academy of Sciences Publishing House: Syktyvkar, Russia, 2009; p. 179. (In Russian)

78. Poradowska, A. Diatoms (Bacillariophyta) from the genus Eunotia and Pinnularia developing on soils in the open landscape of the Low Beskids. J. Ecol. Eng. 2020, 21, 257-270. [CrossRef]

79. Antonelli, M.; Wetzel, C.E.; Ector, L.; Teuling, A.J.; Pfister, L. On the potential for terrestrial diatom communities and diatom indices to identify anthropogenic disturbance in soils. Ecol. Indic. 2017, 75, 73-81. [CrossRef]

80. Venn, J. On the diagrammatic and mechanical representation of propositions and reasonings. Philos. Mag. J. Sci. 1880, 9, 1-18. [CrossRef]

81. Hulsen, T.; de Vlieg, J.; Alkema, W. BioVenn-A web application for the comparison and visualization of biological lists using area-proportional Venn diagrams. BMC Genom. 2008, 9, 488. [CrossRef]

82. Heberle, H.; Meirelles, G.V.; da Silva, F.R.; Telles, G.P.; Minghim, R. InteractiVenn: A web-based tool for the analysis of sets through Venn diagrams. BMC Bioinform. 2015, 16, 169. [CrossRef] [PubMed]

83. Kabirov, R.R.; Safiulina, L.M. Peculiarities of ecology and distribution of unicellular soil alga Eustigmatos magnus (J.B. Petersen) Hibberd in Southern Ural (Russia). Int. J. Algae 2008, 10, 105-116.

84. Hernández, M.; Calabi, M.; Conrad, R.; Dumont, M.G. Analysis of the microbial communities in soils of different ages following volcanic eruptions. Pedosphere 2020, 30, 126-134. [CrossRef]

85. Leff, J.W.; Bardgett, R.D.; Wilkinson, A.; Jackson, B.G.; Pritchard, W.; De Long, J.R.; Oakley, S.; Mason, K.E.; Ostle, M.J.; Johnson, D.; et al. Predicting the structure of soil communities from plant community taxonomy, phylogeny, and traits. Multidiscip. $J$ Microb. Ecol. 2018, 12, 1794-1805. [CrossRef]

86. King, G.M. Contribution of atmospheric $\mathrm{CO}$ and hydrogen uptake to microbial dynamics on recent Hawaiian volcanic deposits. Appl. Environ. Microbiol. 2003, 69, 4067-4075. [CrossRef] [PubMed]

87. Ohta, H.; Yagi, M.; Suzuki, J.; Fujitake, N.; Watanabe, M. Characterization of Sphingomonas species found as predominant members in the culturable bacterial community of a green pigment-containing sclerotium grain from Mt. Myoko (Japan) volcanic ash soil. Microbes Environ. 2003, 18, 126-132. [CrossRef]

88. Gomez-Alvarez, V.; King, G.M.; Nusslein, K. Comparative bacterial diversity in recent Hawaiian volcanic deposits of different ages. FEMS Microbiol. Ecol. 2007, 60, 60-73. [CrossRef]

89. Fujimura, M.; Matsuyama, A.; Harvard, J.P.; Bourdineaud, J.-P.; Nakamura, K. Mercury contamination in humans in Upper Maroni, French Guiana between 2004 and 2009. Bull. Envir. Contamin. Toxicol. 2012, 88, 135-139. [CrossRef]

90. Guo, Z.; Wilson, M.; Zhang, L.; Zhang, M.; Cheng, Z.; Liu, J. The role of subduction channel mélanges and convergent subduction systems in the petrogenesis of post-collisional K-rich mafic magmatism in NW Tibet. Lithos 2014, 198-199, 184-201. [CrossRef]

91. Kim, S.; Kang, J.; Megonigal, J.P.; Kang, H.; Seo, J.; Ding, W. Impacts of Phragmites australis invasion on soil enzyme activities and microbial abundance of tidal marshes. Microb. Ecol. 2018, 76, 782-790. [CrossRef] 
92. Dobrovol'skaya, T.G.; Zvyagintsev, D.G.; Chernov, I.Y.; Golovchenko, A.V.; Zenova, G.M.; Lysak, L.V.; Manucharova, A.; Marfenina, O.E.; Polyanskaya, L.M.; Stepanov, A.L.; et al. The role of microorganisms in the ecological functions of soils. Eurasian Soil Sci. 2015, 48, 959-967. [CrossRef]

93. Geisen, S.; Mitchell, E.A.D.; Adl, S.M.; Bonkowski, M.; Dunthorn, M.; Ekelund, F.; Fernandez, L.D.; Jousset, A.; Krashevska, V.; Singer, D.; et al. Soil protists: A fertile frontier in soil biology research. FEMS Microbiol. Rev. 2018, 42, 293-323. [CrossRef] [PubMed]

94. Wagg, C.; Dudenhöffer, J.H.; Widmer, F.; Heijden, M.G.A. Linking diversity, synchrony and stability in soil microbial communities. Funct. Ecol. 2018, 32, 1280-1292. [CrossRef]

95. Pfister, L.; Wetzel, C.E.; Klaus, J.; Martínez-Carreras, N.; Antonelli, M.; Teuling, A.J.; McDonnell, J.J. Terrestrial diatoms as tracers in catchment hydrology: A review. Wileys Interdiscip. Rev. Water 2017, 4, e1241. [CrossRef]

96. Foets, J.; Stanek-Tarkowska, J.; Teuling, A.J.; Van de Vijver, B.; Wetzel, C.E.; Pfister, L. Autecology of terrestrial diatoms under anthropic disturbance and across climate zones. Ecol. Indic. 2021, 122, 107248. [CrossRef]

97. Wiśniewska, K.; Śliwinska-Wilczewska, S.; Lewandowska, A.; Konik, M. The effect of abiotic factors on abundance and photosynthetic performance of airborne cyanobacteria and microalgae isolated from the Southern Baltic Sea region. Cells 2021, 10, 103. [CrossRef] [PubMed]

98. Metting, B. The systematics and ecology of soil algae. Bot. Rev. 1981, 47, 195-312.

99. Kilham, S.S.; Theriot, E.C.; Fritz, S.C. Linking planktonic diatoms and climabe change in the large lakes of the Yellowstone ecosystem using resource theory. Limnol. Oceanogr. 1996, 41, 1052-1062. [CrossRef]

100. Pan, Y.; Rao, D.V.S.; Mann, K.H.; Li, W.K.W.; Harrison, W.G. Effects of silicate limitation on production of domoic acid, a neurotoxin, by the diatom Pseudo-nitzschia multiseries. II. Continuous culture studies. Mar. Ecol. Progr. 1996, 131, 235-243. [CrossRef]

101. Annett, A.L.; Lapi, S.; Ruth, T.J.; Maldonado, M.T. The effects of $\mathrm{Cu}$ and Fe availability on the growth and $\mathrm{Cu}$ :C ratios of marine diatoms. Limnol. Oceanogr. 2008, 53, 2451-2461. [CrossRef]

102. Kranzler, C.F.; Krause, J.W.; Brzezinski, M.A.; Edwards, B.R.; Biggs, W.P.; Maniscalco, M.; McCrow, J.P.; Van Mooy, B.A.S.; Bidle, K.D.; Allen, A.E.; et al. Silicon limitation facilitates virus infection and mortality of marine diatoms. Nat. Microbiol. 2019, 4, 1790-1797. [CrossRef]

103. Kumar, S.; Rechav, K.; Kaplan-Ashiri, I.; Assaf, G. Imaging and quantifying homeostatic levels of intracellular silicon in diatoms. Sci. Adv. 2020, 6, eaaz7554. [CrossRef]

104. Lukešova, A. Soil algae in brown coal and lignite post-mining areas in Central Europe (Czech Republic and Germany). Restor. Ecol. 2001, 9, 341-350. [CrossRef]

105. Fazlutdinova, A.I.; Sukhanova, N.V. Composition of soil diatoms in zones of impact from oil production complexes. Russ. J. Ecol. 2014, 45, 188-193. [CrossRef]

106. Minaoui, F.; Hakkoum, Z.; Douma, M.; Mouhri, K.; Loudiki, M. Diatom communities as bioindicators of human disturbances on suburban soil quality in arid Marrakesh area (Morocco). Water Air Soil Pollut. 2021, 232, 146. [CrossRef]

107. Ilchibaeva, K.V.; Kunsbaeva, D.F.; Allaguvatova, R.Z.; Fazlutdinova, A.I.; Polokhin, O.V.; Sibirina, L.A.; Gontcharov, A.A.; Singh, P.; Gaysina, L.A. Preliminary data about algae and cyanobacteria of volcanic soils on Kuril islands. Theor. Appl. Ecol. 2018, 4, 119-126. [CrossRef]

108. Lowe, R.L.; Kociolek, P.; Johansen, J.R.; Van De Vijver, B.; Lange-Bertalot, H.; Kopalová, K. Humidophila gen. nov., a new genus for a group of diatoms (Bacillariophyta) formerly within the genus Diadesmis: Species from Hawai'i, including one new species. Diatom Res. 2014, 29, 351-360. [CrossRef]

109. Maltsev, Y.I.; Kulikovskiy, M.S. Morphological and genetic variability of Hantzschia amphioxys (Bacillariophyceae) in terrestrial and aquatic habitats. Botanicheskiy Zhurnal 2017, 102, 1-12. 